\title{
Implications for the use of Osmia cornifrons (Hymenoptera: Megachilidae) as pollinators
}

Joseph Brent White

West Virginia University

Follow this and additional works at: https://researchrepository.wvu.edu/etd

\section{Recommended Citation}

White, Joseph Brent, "Implications for the use of Osmia cornifrons (Hymenoptera: Megachilidae) as pollinators" (2009). Graduate Theses, Dissertations, and Problem Reports. 2789.

https://researchrepository.wvu.edu/etd/2789

This Thesis is protected by copyright and/or related rights. It has been brought to you by the The Research Repository @ WVU with permission from the rights-holder(s). You are free to use this Thesis in any way that is permitted by the copyright and related rights legislation that applies to your use. For other uses you must obtain permission from the rights-holder(s) directly, unless additional rights are indicated by a Creative Commons license in the record and/ or on the work itself. This Thesis has been accepted for inclusion in WVU Graduate Theses, Dissertations, and Problem Reports collection by an authorized administrator of The Research Repository @ WVU. For more information, please contact researchrepository@mail.wvu.edu. 


\title{
Implications for the Use of Osmia cornifrons (Hymenoptera: Megachilidae) as Pollinators
}

\author{
Joseph Brent White
}

Thesis submitted to the College of Agriculture, Forestry and Consumer

Sciences at West Virginia University

in partial fulfillment of the requirements for the degree of

Master of Science

in

Plant and Soil Sciences - Entomology

\author{
Yong-Lak Park, Ph.D., Chair \\ James Amrine, Ph.D. \\ Patrick Tobin, Ph.D. \\ Todd West, Ph.D. \\ Division of Plant and Soil Sciences \\ Morgantown, West Virginia \\ 2009
}

Keywords: Pollination, degree day, bioassay, hornfaced bee, hairy-footed mite

Copyright 2009 Joseph Brent White 


\begin{abstract}
Implications for the Use of Osmia cornifrons (Hymenoptera: Megachilidae) as Pollinators
\end{abstract}

\title{
Joseph Brent White
}

The Japanese hornfaced bees, Osmia cornifrons (Radoszkowski) (Hymenoptera: Megachilidae), is a key pollinator of spring blooming fruit crops such as apple, pear and blueberry. To maximize pollination efficiency, two implications must be considered. First, diapause termination of overwintering $O$. cornifrons adults needs to be synchronized with the bloom of the target trees because adult bees are active as pollinators for only a few weeks. Patterns of temperature-dependent diapause termination of $O$. cornifrons were modeled and simulated with linear and non-linear regression analyses. Results of the study indicated the upper and lower developmental thresholds, as well as the optimum temperature for diapause termination. This study provides a framework for manipulating diapause termination of $O$. cornifrons adults to synchronize their emergence with pollination periods of target crops. Second, O. cornifrons is associated with the hairy-footed mite, Chaetodactylus krombeini Baker (Acari: Chaetodactylidae), which can impede the propagation of $O$. cornifrons. This study was conducted to evaluate formic acid and wintergreen and determine if these compounds would effectively control C. krombeini. This study was conducted in two bioassays: to investigate $O$. cornifrons tolerance of formic acid and wintergreen and to find the lethal concentration of formic acid and wintergreen needed for mite control. Results of this study showed that the time and dosage required to induce $C$. krombeini mortality with either formic acid or wintergreen was significantly less than the time required to produce $O$. cornifrons mortality. Estimates of the $\mathrm{LC}_{50}$ and $\mathrm{LC}_{90}$ for $C$. krombeini hypopi treated with wintergreen were ca. five times lower than those with formic acid, indicating that wintergreen was a more effective chemical that can control the mites. This study provides evidence that $C$. krombeini can be managed effectively with formic acid and wintergreen without inducing mortality in $O$. cornifrons. 


\section{ACKNOWLEDGMENTS}

I would like to thank the Davis College of Agriculture Forestry and Consumer Sciences for allowing me to engage in graduate studies.

I would like to express my deepest gratitude to Dr. Yong-Lak Park, who has served as my major professor and advisor. His guidance, support and patience have made it possible for me to complete this project. I would also like to thank my graduate committee members: Dr. James Amrine for his vast knowledge of all things scientific and his input over the course of this project, Dr. Patrick Tobin for his help with writing and statistical analysis and Dr. Todd West who was very helpful in adding a multidisciplinary approach to this project.

I would like to thank Vicki Kondo for her countless hours of help with this project, from preparing and carrying out experiments to adding valuable insights. She has played an essential role in the project's completion. Also, special thanks to my fellow graduate student, Folukemi Adedipe for her help in assisting with experiments and support along the way. I would like to thank Bob McConnell for supplying countless numbers of Osmia cornifrons for my experiments and his valuable input as one who manages these bees year in and year out.

I would like to thank my parents Frank and Carol who have always supported and encouraged me in whatever I have pursued. Also, I owe a large debt of gratitude to my wife Sandy, who has helped me and endured this process all along the way.

Lastly, I would like to acknowledge Tom McCutcheon, who sadly passed away unexpectedly before the completion of this project; his help, enthusiasm and contributions to this project were invaluable. 


\section{TABLE OF CONTENTS}

Chapter 1 Introduction

Thesis Organization

General Introduction 1

Objective of Study 2

Literature Review 2

References Cited 5

Chapter 2 Temperature-Dependent Diapause Termination

of Osmia cornifrons (Hymenoptera: Megachilidae) Adults

Abstract

11

$\begin{array}{ll}\text { Materials and Methods } & 13\end{array}$

Results 16

$\begin{array}{ll}\text { Discussion } & 19\end{array}$

$\begin{array}{ll}\text { Acknowledgements } & 21\end{array}$

$\begin{array}{ll}\text { References Cited } & 21\end{array}$

Chapter 3 Bioassay of Potential Fumigants to Control Chaetodactylus krombeini

(Acari: Chaetodactylidae) Associated with Osmia cornifrons

(Hymenoptera: Megachilidae)

Abstract

Materials and Methods $\quad 35$

$\begin{array}{ll}\text { Results } & 37\end{array}$

$\begin{array}{ll}\text { Discussion } & 39\end{array}$

Acknowledgements $\quad 41$

References Cited $\quad 41$

Chapter 4 General Conclusion

$\begin{array}{ll}\text { Conclusion } & 49\end{array}$

References Cited $\quad 50$ 


\section{LIST OF TABLES}

Chapter 2 Temperature-Dependent Diapause Termination of Osmia cornifrons (Hymenoptera: Megachilidae) Adults

Table 1. Parameter estimate $( \pm \mathrm{SE})$ of the Weibull model used to estimate median time (d) for diapause termination of overwintering $O$. cornifrons adults at constant temperatures

Table 2. Parameter estimate $( \pm \mathrm{SE})$ of the Weibull model to describe variability of diapause termination rate for the overwintering $O$. cornifrons adults against normalized time ( $\mathrm{d} /$ median)

Table 3. Parameter values $( \pm \mathrm{SE})$ and associated statistics for non-linear model (Rueda et al. 1990) for temperature-dependant diapause termination of $O$. cornifrons adults

Chapter 3 Bioassay of Potential Fumigants to Control Chaetodactylus krombeini (Acari: Chaetodactylidae) Associated with Osmia cornifrons (Hymenoptera:

Megachilidae)

Table 1. Required hours to death of $O$. cornifrons adults with formic acid and wintergreen Treatments

Table 2. Estimates of lethal concentration $\left(\mathrm{LC}_{50}\right)$ of wintergreen (WG) and formic acid (FA) in $O$. cornifrons 


\section{LIST OF FIGURES}

Chapter 1 Introduction

Figure 1. Osmia cornifrons nesting sites $\quad 8$

Figure 2. Generalized diagram of $O$. cornifrons life cycle 9

Figure 3. Generalized diagram of C. krombeini development 10

Chapter 2 Temperature-Dependent Diapause Termination

of Osmia cornifrons (Hymenoptera: Megachilidae) Adults

Figure 1. Device to capture $O$. cornifrons adults after emergence to prevent 27

them from escaping or returning back to the nests.

Figure 2. Temperature-dependant diapause termination of $O$. cornifrons 28 adults fitting with non-linear model.

Figure 3. Cumulative frequency (\%) of development completion for $O$. cornifrons adults fit with Weibull function to the cumulative frequency of normalized age (day/mean development duration)

Figure 4. Simulated temperature-dependent patterns of diapause termination of $O$. cornifrons

Figure 5. Median time (d) required for diapause termination of overwintering $O$. cornifrons males and females at constant temperatures.

Chapter 3 Bioassay of Potential Fumigants to Control Chaetodactylus krombeini (Acari: Chaetodactylidae) Associated with Osmia cornifrons (Hymenoptera: Megachilidae)

Figure 1. Procedures of image analysis to count numbers of C. krombeini hypopi using Adobe Photoshop CS3 Extended

Figure 2. Mortality of $O$. cornifrons adults when wintergreen was applied directly to the bee.

Figure 3. Survivor analysis of $C$. krombeini hypopi when fumigated with

(A) wintergreen and (B) formic acid at three different amount of application: 0 (control), 5, 10, and $20 \mu 1$ per $56.6 \mathrm{~cm}^{3}$ 


\section{CHAPTER 1: INTRODUCTION}

\section{Thesis Organization}

This thesis is organized into four chapters; Chapter 1 is a general introduction to the project and a literature review. Chapter 2 provides a framework for temperature dependent diapause termination of Japanese hornfaced bee, Osmia cornifrons (Radoszkowski) (Hymenoptera: Megachilidae) adults. Chapter 3 addresses possible control methods for the hairy-footed mite, Chaetodactylus krombeini Baker (Acari: Chaetodactylidae) associated with $O$. cornifrons. Chapter 4 provides a general conclusion for this study. This thesis was prepared according to the publication guidelines established by the Entomological Society of America.

\section{General Introduction}

Crop and fruit pollination is a $\$ 15$ billion industry each year in the United States (Morse and Calderone 2000). With recent events such as parasitic mites (Finley 1995), Africanized honeybees (Sammataro and Avitable 1998) and Colony Collapse Disorder (Stokstad 2007) contributing to the decline of honey bees Apis mellifera (L.) (Hymenoptera: Apidae), there is a need to consider alternate means of pollination (Adams 2001). Osmia cornifrons has been used successfully for the pollination of apple in Japan (Sekita and Yamada 1993), and since its introduction to the United States in 1976 (Batra 1998), it has been used for the pollination of spring blooming fruit trees (Batra 1998, Adams 2001) and vegetable crops (Wilson et al. 1999). Because the life cycle of the bee coincides well with blueberry flowering it is particularly attractive for blueberry pollination (West and McCutcheon 2005). Like other solitary hymenoptera, $O$. cornifrons is timid and rarely stings. In addition, it can be readily managed and propagated in commercial orchards (Batra 1998, Bosch and Kemp 2001). However, there are 
several pests associated with $O$. cornifrons and $C$. krombeini is a major pest infesting the nesting sites of $O$. cornifrons. The large mite populations compete with developing larvae for pollen provisions, which leads to increased larval mortality causing reductions in $O$. cornifrons populations.

\section{Objectives of Study}

The goal of this study was to investigate two major problems facing $O$. cornifrons management and to develop possible solutions to utilize the bee for its maximum pollination potential. The objectives of this research were:

1. To model the relationship between temperature and diapause termination of $O$. cornifrons adults (Chapter 2).

2. To develop methods of controlling the pollen mite C. krombeini infesting O. cornifrons nesting sites (Chapter 3).

\section{Literature Review}

Life History of $\boldsymbol{O}$. cornifrons and $\boldsymbol{C}$. krombeini. Osmia cornifrons is native to Japan and introduced to the United States in 1973 (Batra 1998). It undergoes one generation per year. Adult bees spend only a few weeks actively engaged in pollination, which is typical for most solitary hymenopterans allowing the bee to spend only a few weeks actively engaged in pollination. Most of the life cycle is spent undergoing development and diapause as adult bees inside nests. Osmia cornifrons adults emerge from their nests in early April, mate immediately, and females then begin laying eggs and foraging. Female bees make pollen provisions for the eggs that have been laid inside nests. Adults die in early June and the eggs hatch and begin to 
develop while feeding on the pollen provisions. Immature $O$. cornifrons complete larval and pupal development and remain in cocoons as adults inside nests from October until April of the following year (Fig. 1).

Under natural conditions, Osmia spp. (e.g., O. cornifrons and O. lignaria) can be found nesting in reeds. In commercial settings, however, it is commonly managed in small cardboard tubes used as nests (Batra 1998, Bosch and Kemp 2001). Osmia cornifrons is gregarious and the tubes facilitate their use in a targeted area. Osmia cornifrons constructs cells with mud partitions within the tubes which can be grouped together in bundles (Fig. 2). While this makes management easier it also provides an attractive habitat for natural enemies and pests such as parasitic wasps and mites (Krunić et al.2005, Park et al. 2009).

One pest associated with $O$. cornifrons is $C$. krombeini, and it is of particular importance with respect to O. cornifrons propagation and management (Park et al. 2009). Chaetodactylus krombeini is a pollen mite that infests the tubes in which Osmia spp. nest (Bosch and Kemp 2001). The life cycle of $C$. krombeini has several stages including immature, reproductive, migratory, and cyst stages. As an immature protonymph, the mite can either continue to develop into the reproductive stage, change into the migratory (hypopus) stage or become dormant in the cyst stage. Chaetodactylus krombeini hypopi enters nesting tubes in a variety of ways. In general, a major dispersal mechanism of the mite is through phoretic behavior. When $C$. krombeini hypopi hitchhike on $O$. cornifrons adults, hypopi become entangled in the hairs of the bee. Park et al. (2009) found that C. krombeini hypopi were capable of walking from adjacent tube openings as well as through holes in tubes created by parasitic wasps. Once hypopi enter the tubes their population can increase to 170 to 5000 mites per cell in the nest (Park et al. 2009). Chaetodactylus krombeini populations are cleptoparasitic and compete with $O$. cornifrons larvae 
for pollen provision in the tubes and have been reported to kill developing larvae (Bosch and Kemp 2001). Larvae that do survive may experience a reduction in size due to a decreased food supply during development (Bosch and Kemp 2001).

Modeling Temperature Dependent Diapause Termination. During the last several decades, temperature-dependent insect growth and development has been modeled with linear and non-linear regression (Wagner et al. 1984a and b). Such models provide predictions of insect life cycle (e.g. events, predicting emergence or peak population periods), which can be used for management of insects. Because diapause termination of $O$. cornifrons is also temperature-dependent (Yamada et al. 1971, Adams 2001) these regression approaches can be used to predict diapause termination of $O$. cornifrons adults. Linear regression can be used to determine the lower temperature threshold and non-linear regression can be used to determine the optimum and upper temperature thresholds. This study was conducted to provide a framework for manipulating $O$. cornifrons diapause termination so that growers can more effectively synchronize plant blooming period with flower visiting period of $O$. cornifrons.

Management of C. krombeini. Mites associated with honeybees have been effectively controlled with both formic acid and essential oils when used as fumigants (Amrine 2006, Amrine and Noel 2006). This method of fumigation is attractive as a control method because it does not disrupt the honeybees in the hive and the treatments are accepted as organic methods of control. Management of $C$. krombeini can be difficult because the mite has several different life stages, and is currently achieved both mechanically and chemically. Heat treatments have been used for C. krombeini control (Bosch and Kemp 2001). When nests of Osmia spp. infested with C. krombeini were exposed to high temperatures, the bees remained alive while the mites died. Another approach to control C. krombeini is the use of binder boards (i.e., boards with the 
appropriate sized hole drilled through and then cut in half) allowing one to pry the two pieces of the board apart, gaining access to the cocoon inside (Strickler 2002). The binder boards can be used for $C$. krombeini control by opening the boards and removing the cocoons to separate those infested with C. krombeini. Cocoons that have been removed from binder boards also can be washed with a bleach solution (Strickler 2009). However, all of these methods may produce side effects. When chemicals are used, cocoons and nesting materials come into direct contact with the chemicals, which can cause chemical residue inside the nesting materials. Also, the physical removal of $O$. cornifrons from the binder boards generally results in releasing loose cocoons and may increase dispersal of pre-nesting female bees (Bosch and Kemp 2001); generally females leave their nesting tubes to feed for a few days and then return to lay eggs, while those females who have been released outside of their nesting tube have a greater chance of not returning to lay eggs.

\section{References Cited}

Adams, L. R. 2001. Determination of accumulation of degree days required for the emergence of Osmia cornifrons (Megachillidae) in Pennsylvania. M.S. thesis. Pennsylvania State University, College Park, PA.

Amrine, J. W. 2006. Wintergreen + Salt Grease Patties. http://www.wvu.edu/ agexten/varroa/GresPates.pdf.

Amrine, J. W. and R. Noel. 2006. Formic acid fumigator for controlling varroa mites in honey bee hives. Int. J. Acarol. 32: 115-124.

Batra, S. W. T. 1998. Management of hornfaced bees for orchard pollination. University of Idaho, Moscow, ID. 
Bosch, J., and W. P. Kemp. 2002. Developing and establishing bee species as crop pollinators: the example of Osmia spp. (Hymenoptera : Megachilidae) and fruit trees. Bull. Entomol. Res. 92: 3-16.

Finley, J. V. 1995. Acaricide treatments of tracheal and varroa mite infestations of honeybees, and the development of geographically-referenced menthol treatment recommendations of Pennsylvania. M.S. thesis

Krunić, M., L. Stanisaljevic, M. Pinzauti, and A. Felicioli. 2005. The accompanying fauna of Osmia cornuta and Osmia rufa and effective measures of protection. Bullet. Insect. 58: $141-152$.

Morse, R.A., and N. W. Calderone. 2000. The value of honey bees as pollinators of U.S. crops in 2000. Bee Cult. 128: 2-15.

Park, Y. L., V. Kondo. J. White, T. West, B. McConnell, and T. McCutcheon. 2009. Nest-tonest dispersal of Chaetodactylus krombeini (Acari, Chaetodactylidae) associated with Osmia cornifrons (Hym., Megachilidae). J. Appl. Entomol. 133: 174-180.

Sammataro, D. B., and A. Avitable. 1998. The Beekeeper's Handbook $3^{\text {rd }}$ Edition. Cornell Press, NY.

Sekita, N., and M. Yamada. 1993. Use of Osmia cornifrons (Radoszkowski) for pollination of apples in Aomori Prefecture, Japan. Jap. Agric. Res. Quart. 26: 264-270.

Strickler, K. 2009. Winter Cocoon Management. http://www.pollinatorparadise.com/Solitary_Bees/Winter_Cocoon_Management.htm\#Rem oving_loose_cocoons.

Strickler, K., and J. Mills 2002. Loose cell management systems for solitary bees. http://www.pollinatorparadise.com/Binderboards/Osmiabb.htm. 
Stokstad, E. 2007. The case of the empty hives. Science 316: 970-972.

Wagner, T. L., H. I. Wu, P. J. H. Sharpe, and R. N. Coulson. 1984a. Modeling distribution of insect development rates: a literature review and application of the Weibull function. Ann. Entomol. Soc. Am. 77: 475-487.

Wagner, T. L., H. I. Wu, P. J. H. Sharpe, R. Schoolfield, and R. N. Coulson. 1984b. Modeling insect development rates: a literature review and application of a biophysical model. Ann. Entomol. Soc. Am. 77: 208-225.

West, T. P., and T. W. McCutcheon. 2005. Evaluating hornfaced bees (Osmia cornifrons) as pollinators of highbush blueberry. Hortscience 41: 1012.

Wilson, R. L., C. A. Abel, and S. G. McClurg. 1999. Osmia spp. reared in artificial nesting sites in a backyard environment. J. Iowa Acad. Sci. 106: 4-7.

Yamada, M., N. Oyama, N. Sekiga, S. Shirasaki, and C. Tsugawa. 1971. The ecology of megachilid bee, Osmia cornifrons Radoszkowski (Hymenoptera: Apidae) and its utilization for apple pollination. Bull. Aomori Apple Exp. Station, No. 15. Aomori, Japan. 

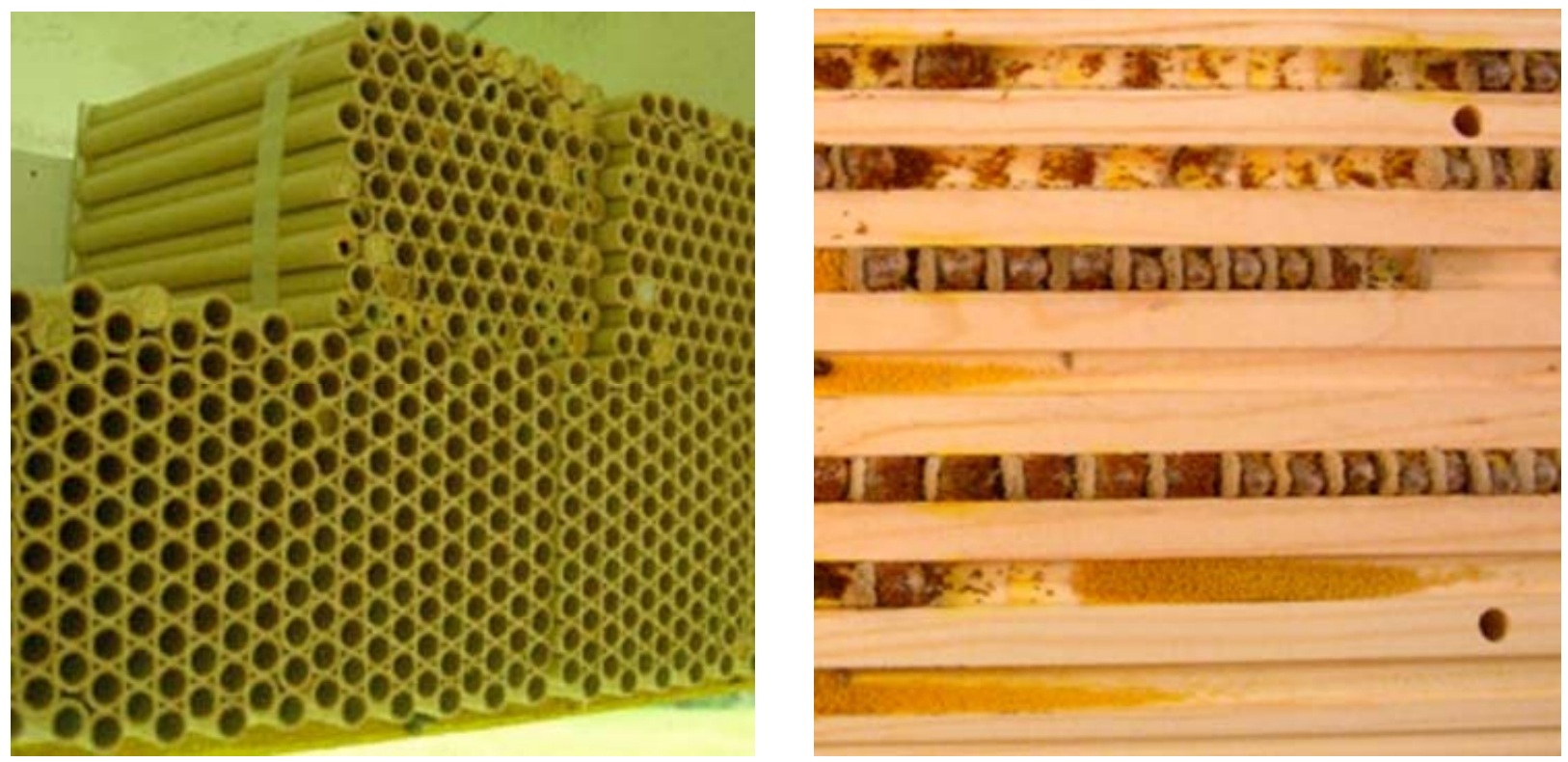

Figure 1: Grouping of cardboard tubes (left) used for $O$. cornifrons nesting sites and crosssection (right) of $O$. cornifrons nests. Note that the tubes closed with mud (left) indicate that nested tubes by $O$. cornifrons. 


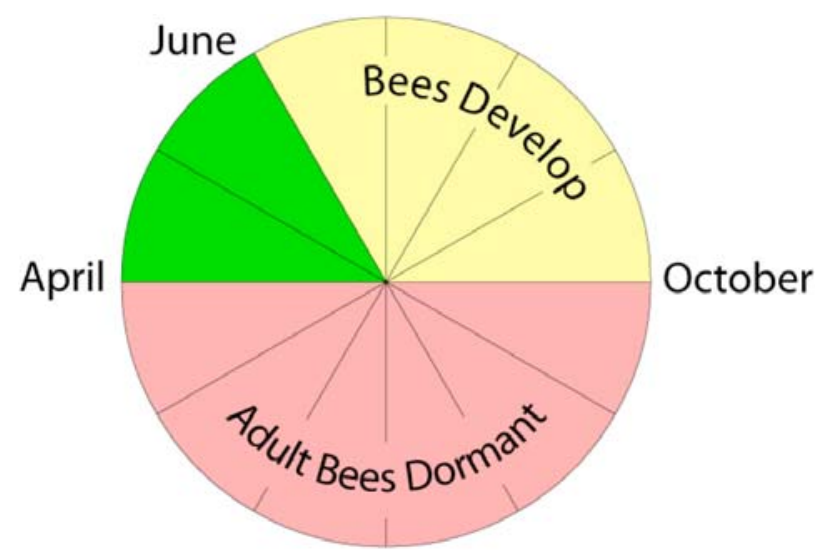

Figure 2: Life cycle $O$. cornifrons. Adult bees emerge from diapause in April and are active until June. Development occurs from June through October and adult bees undergo diapause until the following April. 
Figure 3

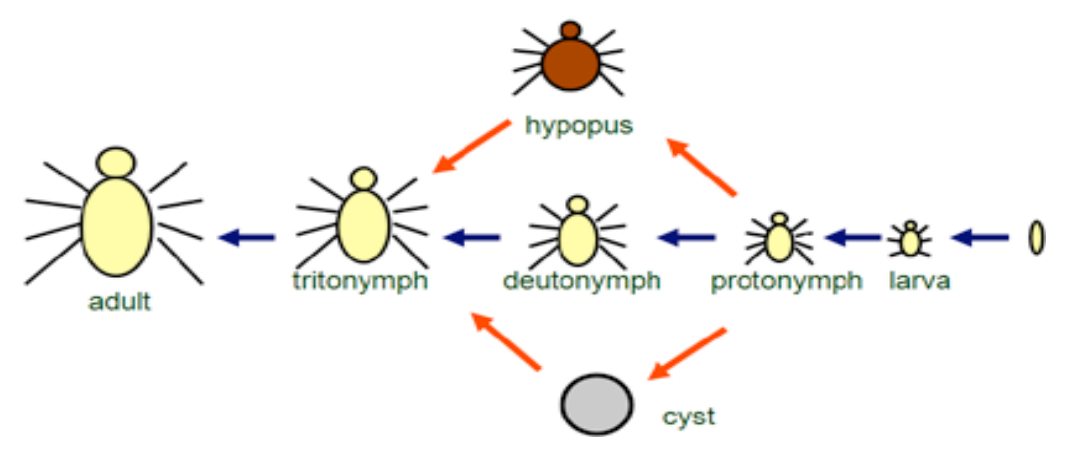

Figure 3: Generalized diagram of C. krombeini potential development. Note that at the protonymph stage, the mite can assume one of three different forms including regular duetonymph, migratory duetonymph (hypopus), or dormant deutonymph (cyst). 


\title{
CHAPTER 2: Temperature-Dependent Diapause Termination of Osmia cornifrons (Hymenoptera: Megachilidae) Adults
}

\begin{abstract}
Japanese hornfaced bees, Osmia cornifrons (Radoszkowski), are key pollinators of spring blooming fruit crops such as apple, pear and blueberry. To maximize pollination of the fruit crops, diapause termination of overwintering $O$. cornifrons adults needs to be synchronized with the bloom of the target trees because adult bees are active as pollinators for only a few weeks. This study was conducted to determine lower temperature thresholds (LTD), optimum temperatures, and required degree-day accumulation for diapause termination of $O$. cornifrons adults. Patterns of temperature-dependent diapause termination of $O$. cornifrons adults at seven temperatures $\left(4,12,19,27,30,36\right.$ and $\left.43{ }^{\circ} \mathrm{C}\right)$ were modeled and simulated with linear and nonlinear regression analyses. Results showed that the required degree-days for diapause termination of male and female $O$. cornifrons adults were 125.2 with a LTD of $8.91^{\circ} \mathrm{C}$, and 179.8 with a LTD of $8.60^{\circ} \mathrm{C}$, respectively. The optimum temperatures for diapause termination were $35.5,30.0$, and $36.0^{\circ} \mathrm{C}$ for male, female, and both sexes combined, respectively. This study provides a framework for manipulating diapause termination of $O$. cornifrons adults to synchronize their emergence with pollination periods of target fruiting crops.
\end{abstract}

Keywords: pollination, degree day, hornfaced bee 
With the recent decline of honey bee populations, Apis mellifera (L.) (Hymenoptera: Apidae) (Stokstad 2007) it has become necessary to find alternate and supplemental methods of pollination in the United States (Winfree et al. 2008). A potential substitute or supplemental pollinator is the Japanese hornfaced bee, Osmia cornifrons (Radoszkowski) (Hymenoptera: Megachilidae), which is native to Japan. Osmia cornifrons has been used as a key pollinator of spring blooming fruit trees such as apple and pear in the United States (Batra 1998, Adams 2001, Bosch and Kemp 2002, Matsumoto et al. 2008) since it was introduced from Japan in the 1970's (Batra 1998). West and McCutcheon (2005) reported the potential use for pollinating small fruit crops such as blueberry. Although $O$. cornifrons is a solitary bee nesting in reeds and holes in the field, it exhibits gregarious behavior when managed commercially in bundles of artificial nests such as cardboard tubes and wood blocks with holes (Batra 1998, Wilson et al. 1999, Park et al. 2009). Like many solitary hymenoptera $O$. cornifrons is timid and rarely stings, it can be readily managed and propagated in commercial orchards (Batra 1998).

The life cycle of $O$. cornifrons, which is typical for most solitary hymenopterans, poses a problem because $O$. cornifrons spends only a few weeks actively engaged in pollination. Most of the life cycle is spent undergoing development followed by diapause as adult bees inside nests. As a result of the short pollination activity of $O$. cornifrons adults, growers need to ensure that adult bees are active blooming occurs to maximize pollination. Adding to the complexity of synchronization, target crops may have different pollination periods. For example, blueberry can have different bloom schedules, from April to June, depending on the variety (Pritts and Hancock 1992). One way to synchronize emergence with bloom is to manipulate diapause termination of adult bees. Adults undergo diapause inside cocoons during the winter, and diapause termination is temperature-dependent (Yamada 1971, Adams 2001). Adults break diapause and emerge from 
their cocoons once the required heat units (i.e. degree-days) are accumulated. Therefore, it would be possible to manipulate $O$. cornifrons adult diapause termination to synchronize it with pollination periods of target crops.

During the last 20 years, temperature-dependent insect growth and development has been modeled with linear and non-linear regression (Wagner et al. 1984a and b). Such models provide predictions of insect life cycle (e.g. events, predicting emergence or peak population periods), which can be used for management of insects. Because diapause termination of $O$. cornifrons is also temperature-dependent (Yamada et al. 1971, Adams 2001) these regression approaches can be used to predict diapause termination of $O$. cornifrons adults. This study was conducted to predict diapause termination of $O$. cornifrons by modeling temperature-dependent diapause termination patterns at various temperature regimes. Linear regression was used to determine the lower temperature threshold and non-linear regression was used to determine the optimum and upper temperature thresholds. This study provides a framework for manipulating $O$. cornifrons diapause termination so that growers can synchronize plant blooming period with flower visiting period of $O$. cornifrons.

\section{Materials and Methods}

Colony source. Colonies of $O$. cornifrons were obtained from a local grower in Independence, West Virginia, who had been using $O$. cornifrons to pollinate blueberry for the last 10 years. The grower used cardboard tubes $(7.9 \mathrm{~mm}$. diameter, $0.8 \mathrm{~mm}$ thickness, and 152 mm length; Jonesville Paper Tube Co., Jonesville, MI, U.S.A.) as artificial nests for $O$.

cornifrons. Prior to the experiment, the colonies of $O$. cornifrons were stored in the field during their developmental period and then stored at $4^{\circ} \mathrm{C}$ in a climate controlled container throughout their diapause period during the winter of 2007-2008. 
Experimental design. The experiment was conducted in seven environmental chambers (I-60LVL, Percival Scientific, Boone, IA) maintained at 4, 12, 19, 27, 30, 36 or $42^{\circ} \mathrm{C}$. These temperatures were chosen to expand on the temperature gradient used by Adams (2001). Temperature in each environmental chamber was monitored with a HOBO data logger (H08007-02, OnSet Computer Corporation, Pocasset, MA) and photoperiod was kept constant at 9:15 (L:D) hr to simulate photoperiod conditions when bees would be active. In our preliminary study, we observed that some $O$. cornifrons adults returned back to their nests after emerging from the nests, so sometimes it was difficult to confirm if they emerged and subsequently returned back to their nests to hide. Therefore, we designed bundles of tubes to effectively monitor emergence of $O$. cornifrons adults from the artificial nests. A total of 25 randomlyselected cardboard nests with diapausing adults from the field were bundled and placed in a 0.3liter clear water bottle that was cut in half (Fig. 1). The bottom portion of a water bottle was used to cover the bundle to prevent $O$. cornifrons from escaping from the nests. Tanglefoot ${ }^{\circledR}$ (Tanglefoot, Grand Rapids, MI, U.S.A.) was coated inside the bottom portion of a water bottle to prevent $O$. cornifrons adults from returning back to the nest after emergence from the nest. In each environmental chamber, 100 cardboard nests (i.e. four bundles with 25 cardboard nests per bundle) were placed and the number of emerged $O$. cornifrons adults was checked daily until all live bees emerged from the nests. The sex of emerged $O$. cornifrons adults was also determined.

Developmental distribution. Cumulative frequency distributions of diapause termination of $O$. cornifrons adults were quantified at each constant temperature to estimate median development time by using a Weibull function (Régnière 1984, Wagner et al. 1984a). We used a two-parameter Weibull function expressed as

$$
P(x)=100-100 \times \exp \left[-(x / \alpha)^{\beta}\right],
$$


where $P(x)$ is the cumulative frequency (\%) at time $x$ in days, á is scale parameter, and $\hat{\mathrm{a}}$ is a shape parameter. Prior to fitting the frequency data to the Weibull function, the percentile cumulative diapause termination over time (d) for each temperature was calculated (Wagner et al. 1984a). Temperature-independent distribution curves were also generated by applying the Weibull equation against normalized time; the normalized time was calculated by dividing the time by the median time estimated at each temperature.

Development rate models. Rates of diapause termination (1/d) were modeled with the nonlinear biophysical model (Sharpe and DeMichele 1977) and the linear degree-day model (Campbell et al. 1974). The linear portion (excluding data collected from 4 and $42^{\circ} \mathrm{C}$ because of no emergence at these temperatures) of the rate of the diapause termination curve was modeled using linear regression (PROC REG, SAS Institute 2008). The lower temperature threshold for diapause termination was estimated by the $x$ intercept of the regression fit, and the degree-day requirement for diapause termination of $O$. corniforns adults was estimated from the inverse slope of the regression fit (Arnold 1959, Campbell et al. 1974).

The rates of diapause termination at seven different temperatures were fit with a fourparameter non-linear model (Sharpe and DeMicheal 1977, Rueda 1990) according to:

$$
r(\mathrm{~T})=\frac{\mathrm{RHO} 25 \frac{\mathrm{T}}{298.15} \exp \left[\frac{\mathrm{HA}}{\mathrm{R}}\left(\frac{1}{298.15}-\frac{1}{\mathrm{~T}}\right)\right]}{1+\exp \left[\frac{\mathrm{HH}}{\mathrm{R}}\left(\frac{1}{\mathrm{TH}}-\frac{1}{\mathrm{~T}}\right)\right]},
$$

where $r(\mathrm{~T})$ is rate of growth at temperature $\mathrm{T}\left({ }^{\circ} \mathrm{Kelvin}\right), \mathrm{RHO} 25$ is the development rate at $25^{\circ} \mathrm{C}$, HA is enthalpy of activation by rate controlling enzyme, $\mathrm{R}$ is universal gas constant set as 1.987 , $\mathrm{TH}$ is the ${ }^{\circ}$ Kelvin at which enzyme is one part active and one part inactive do to high temperature, and $\mathrm{HH}$ is the change in enthalpy associated with high-temperature inactivity. The 
rate of diapause termination was modeled using non-linear regression (PROC NLIN, SAS Institute 2008) outlined by Wagner et al. (1984b) from which temperature thresholds and optimum temperatures for diapause termination were estimated.

Simulation of diapause termination pattern. The emergence of adults terminating diapause was simulated in relation to constant temperature $\left({ }^{\circ} \mathrm{C}\right)$ and time (d) by combining the Weibull distribution and the biophysical rate models. The rate model determined the daily rate of diapause termination at a given temperature, and the distribution model determined the cumulative frequency in the population (Curry et al. 1978, Allen et al. 1995, Son and Lewis 2005). Daily rate of diapause termination is $R(\mathrm{~T})$ at a certain constant temperature $\mathrm{T}$, and the rate summed up to time $x$ is calculated by multiplying the time $x$ with the daily rate $R(\mathrm{~T})$ (Wagner et al. 1985). The rate summed up to time is equal to $x \times R(\mathrm{~T})$, where $x$ is time (d). Therefore, the mathematical expression of the simulation model is,

$$
F(x, T)=100-100 \cdot \exp \left(-\left[\frac{x R(T)}{\alpha}\right]^{\beta}\right)
$$

where $F(x, T)$ is the cumulative frequency $(\%)$ of the diapause termination at time $x$ and constant temperature $T, R(T)$ is the temperature-dependent rate model; $x$ is time (d), and á and â are the scale and shape parameters, respectively, from the Weibull function fit to normalized time. At each temperature, simulated values were demonstrated as frequency (\%) of the adults completing diapause during day ${ }_{i}$, for instance, which was calculated by subtracting the

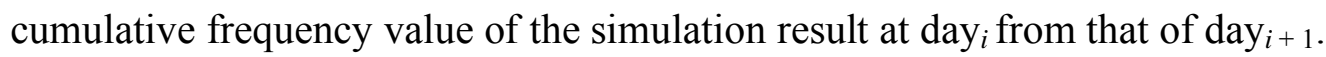

\section{Results}

Emergence patterns of $O$. cornifrons adults depended upon the temperature to which they were exposed (Table 1 and Fig. 2). No O. cornifrons adults emerged at the two extreme 
temperatures (i.e. 4 and $42^{\circ} \mathrm{C}$ ). Among the five temperature regimes where $O$. cornifrons adult emergence occurred, the slowest emergence was observed at $12^{\circ} \mathrm{C}$ when the first adult bees (males) emerged after $26 \mathrm{~d}$. In contrast, the quickest adult emergence (males) was observed at $36^{\circ} \mathrm{C}$ where emergence occurred after as early as $3 \mathrm{~d}$. The first female bees that terminated diapause at $30^{\circ} \mathrm{C}$ took $8 \mathrm{~d}$ longer than the first males. At these two extreme temperatures where emergence did occur, the number of $O$. cornifrons adults emerged was $\approx 17$ fold lower than the number that emerged at $19^{\circ} \mathrm{C}$, indicating that $O$. cornifrons emergence may be obtained quickly at high temperatures but with a decreased number of emerging adults.

Cumulative frequency distributions of diapause termination for the adults at each temperature were well described by the Weibull model (all $\left.r^{2}>0.85 ; P<0.01\right)$ (Table 1$)$. In 12 $30.3^{\circ} \mathrm{C}$ where adults in both sexes emerged, it took longer for female $O$. cornifrons to terminate diapause than males (Fig. 2). The differences in the estimated median time for diapause termination between males and females became smaller as temperature increases, ranging from $2.1 \mathrm{~d}$ at $26.6^{\circ} \mathrm{C}$ to $8.8 \mathrm{~d}$ at $12^{\circ} \mathrm{C}$.

The cumulative distribution against normalized time (d/median) was also well explained by the Weibull function for $O$. cornifrons males $\left(F=400.6\right.$; d.f. $=1,41 ; P<0.001, r^{2}=0.91$ ), females $\left(F=1323.1 ;\right.$ d.f. $\left.=1,28 ; P<0.001, r^{2}=0.98\right)$ and the combined data $(F=1899.0$; d.f. $=$ 1, 53; $P<0.001, r^{2}=0.97$ ) (Fig. 2 and Table 2). A higher value of the parameter ( $\beta$ ) in the Weibull indicated the lower variability in the distribution; diapause termination of females ( $\beta=$ 9.64) exhibited less variation than that of males $(\beta=5.92)$.

Relationships between rate of diapause termination (y) and temperature $(x)$ were $y=$ $0.007989 \times x-0.07122\left(\mathrm{~F}=210.6 ;\right.$ d.f. $\left.=1,3 ; \mathrm{P}<0.01 ; r^{2}=0.99\right)$ for male bees and $y=0.00562$ $\times x-0.04784\left(\mathrm{~F}=99.9 ;\right.$ d.f. $\left.=1,2 ; \mathrm{P}<0.01 ; r^{2}=0.98\right)$ for female bees. The slope for male $O$. 
cornifrons was greater than that of females, indicating male $O$. cornifrons broke diapause earlier than females. When male and female data were combined, the relationship was $y=0.007927 \times$ $x-0.08326\left(\mathrm{~F}=39.2 ;\right.$ d.f. $\left.=1,3 ; \mathrm{P}<0.01 ; r^{2}=0.93\right)$. Based on these equations, lower temperatures for diapause termination were $8.9,8.6$ and $10.5^{\circ} \mathrm{C}$ for male, female and both sex combined, respectively. Required degree-days for diapause termination of male and female $O$. cornifrons were 125.2 and 179.8, respectively. When male and female data were combined, degree-days required for diapause termination was 126.1 degree-days, which may be do, impart, because the sex ratio favored males over females.

Although the linear regression model can provide values for lower temperature thresholds and degree-day requirements for diapause termination, it does not indicate the upper threshold and the optimum temperature at which $O$. cornifrons adults break diapause. The non-linear models (Table 3 and Fig. 3) showed that the upper thresholds for $O$. cornifrons adult diapause termination were $\approx 41.2,37.1$, and $42.3^{\circ} \mathrm{C}$ for male, female, and both sex combined, respectively. The optimum temperatures were $35.7,30.2$, and $36.5^{\circ} \mathrm{C}$ for male, female, and both sex combined, respectively.

Simulation models enable us to predict when the adult emergence upon diapause completion would occur over a full range of constant temperatures (Fig. 4). At optimum temperatures the emergence density curve exhibited lower variance and shortest time for the diapause termination. At very low and very high temperatures, the emergence time would be delayed with higher variation among cohorts. Female $O$. cornifrons would have a narrower range of temperature during their diapause completion than males, which is more evident at higher temperatures. For example, more than $99 \%$ of males would terminate diapause at $9.0-38.5^{\circ} \mathrm{C}$ 
within a period of $60 \mathrm{~d}$ while the same percentage of females would terminate diapause within 60 d at $13.5-32.5^{\circ} \mathrm{C}$.

\section{Discussion}

To maximize pollination, diapause termination of overwintering $O$. cornifrons adults must be synchronized with the bloom of the target crop. In this study we found that diapause termination of $O$. cornifrons adults could be manipulated by exposing them to specific temperatures. Although diapause of $O$. cornifrons adults could be terminated within $3 \mathrm{~d}$ after placing them at $36^{\circ} \mathrm{C}$, the largest number of bees emerged at $19^{\circ} \mathrm{C}$. There was a 17 -fold increase in total adult bee emergence at $19^{\circ} \mathrm{C}$ compared to $36^{\circ} \mathrm{C}$, indicating a trade-off between expediting diapause termination and maximizing the number of emerged bees. This suggests that growers would need to place overwintering $O$. cornifrons adults at certain temperatures depending on how urgently they needed or how many they needed for crop pollination. In any case, excessively high or low temperatures should be avoided since we observed no emerging $O$. cornifrons at $4{ }^{\circ} \mathrm{C}$ and $42^{\circ} \mathrm{C}$. This knowledge of upper and lower temperature thresholds for diapause termination along with optimum temperatures for largest emergence and fastest diapause break can allow growers to release $O$. cornifrons adults in a timely manner.

A few previous studies attempted to determine the degree-day requirement for development and diapause termination of $O$. cornifrons. Yamada et al. (1971) conducted an experiment with five different temperatures and reported that $25^{\circ} \mathrm{C}$ was the optimum temperature for development from hatching to pupation. Adams (2001) reported that the lower temperature threshold for diapause termination was $6.04^{\circ} \mathrm{C}$ and the degree days required for emergence was 182, which was different from our results (i.e. a lower temperature threshold of $10.50^{\circ} \mathrm{C}$ and a degree-day requirement of 126.1). This may be due to different experimental procedures 
between the two studies. Adams (2001) conducted the experiment for temperature-dependent diapause termination of $O$. cornifrons adults by removing them from their nests and placing them in plastic cups at five different temperatures. In our study, we attempted to simulate actual field conditions, so we allowed the $O$. cornifrons to remain in their nests in the growth chambers. In addition, we considered two extreme temperatures to model and simulate non-linear temperaturedependent diapause termination of $O$. cornifrons adults with seven different temperatures.

Since $O$. cornifrons adults spend a very short period of their life cycle engaged in pollination, it is crucial to synchronize the termination of diapause with the blooming period of the target plant to maximize pollination. There are three major applications of diapause termination of $O$. cornifrons adults for pollination. First, the lower and higher temperature thresholds can be used to determine temperatures for proper storage and termination of diapausing $O$. cornifrons adults during the winter. Diapausing $O$. cornifrons adults would need to be stored under the lower temperature threshold during the winter to maintain diapauses, and under the high temperature threshold to avoid mortality. Second, knowing the degree day requirements for $O$. cornifrons adult emergence allows for a more goal oriented release of $O$. cornifrons adults. For example, if a large number of bees are required over an extended period of time, then it might be advisable to expose $O$. cornifrons to optimum temperatures. However, when emergence of $O$. cornifrons adults is needed immediately and the number of emerged adults is less important, it would be necessary to expose the diapausing adult bees to higher temperatures. Likewise, if emergence needs to be delayed, then a temperature below the optimal temperature could be used to prolong diapause. However, prolonging diapause also decreases the total number of emerged adults. Third, growers need to consider sexual differences when manipulating diapause termination because female $O$. cornifrons are better pollinators (Bosch 
and Kemp 2002). This study showed that females would emerge later than males with a shorter range of diapause termination period. Our simulation for female emergence would be a useful predictive tool and yet the actual emergence of males can be used as a reliable indicator of predicting female emergence (Fig. 5).

The results of this study indicated that diapause termination of $O$. cornifrons adults could be manipulated, based on models of diapause termination patterns, to synchronize adult bee emergence with the pollination periods of target fruit trees. Trade-offs between expedited termination of diapause and decreased bee abundance could be determined depending on various factors in each orchard such as the size of managing $O$. cornifrons colonies, climatic conditions, and fruit tree varieties varying blooming periods.

\section{Acknowledgments}

We thank Bob McConnell for providing Osmia cornifrons for this experiment. We also thank Todd West, Jim Amrine, and Vicki Kondo at West Virginia University and Patrick Tobin at U.S. Forest Service for their valuable suggestions related to this experiment. This project was supported by the Division of Plant and Soil Science at West Virginia University and the Sustainable Agriculture Research and Education Grant program.

\section{References Cited}

Adams, L. R. 2001. Determination of accumulation of degree days required for the emergence of Osmia cornifrons (Megachillidae) in Pennsylvania. M.S. thesis. Pennsylvania State University, College Park, PA.

Allen, J. C., Y. Yang, and K. L. Knapp. 1995. Temperature effects on development and fecundity of the citrus rust mite (Acari: Eriophyidae). Environ. Entomol. 24: 996-1004.

Arnold, C. Y. 1959. The development and significance of the base temperature in a linear heat 
unit system. Proc. Am. Soc. Hort. Sci. 74: 430-445.

Batra, S. W. T. 1998. Management of hornfaced bees for orchard pollination. University of Idaho, Moscow, ID.

Bosch, J., and W. P. Kemp. 2002. Developing and establishing bee species as crop pollinators: the example of Osmia spp. (Hymenoptera : Megachilidae) and fruit trees. Bull. Entomol. Res. 92: 3-16.

Campbell, A., B. D. Frazer, N. Gilbert, P. Gutierrez, and M. Mackauer 1974. Temperature requirements of some aphids and their parasites. J. Appl. Ecol. 11: 431-38.

Curry, G. L., R. M. Feldman, and P. J. H. Sharpe. 1978. Foundations of stochastic development. J. Theor. Biol. 74: 397-410.

Matsumoto, S., T. Eguchi, T. Maejima, and H. Komatsu. 2008. Effect of distance from early flowering pollinizers 'Maypole' and 'Dolgo' on 'Fiji' fruit set. Sci. Hort. 117: 151-159.

Park, Y. L., V. Kondo. J. White, T. West, B. McConnell, and T. McCutcheon. 2009. Nest-tonest dispersal of Chaetodactylus krombeini (Acari, Chaetodactylidae) associated with Osmia cornifrons (Hym., Megachilidae). J. Appl. Entomol. 133: 174-180.

Pritts, M. P., and J. F. Hancock. 1992. Highbush blueberry production guide. Northeast Regional Agricultural Engineering Service, Cooperative Extension. Ithaca, NY.

Régnière, J. 1984. A method for describing and using variability in development rates for simulation of insect phenology. Can. Entomol. 116:1367-1376.

Rueda, L. M., K. J. Patel, R. C. Axtell, and R. E. Stinner. 1990. Temperature-dependent development and survival of Culex quinquefasciatus and Aedes aegypti (Diptera: Culicidae). J. Med. Entomol. 27: 892-898.

SAS Institute. 2008. SAS OnlineDoc ${ }^{\circledR}$ version 9.1.3. SAS Institute. Cary, NC. 
Sharpe, P. J. H., and D. V. DeMichele. 1977. Reaction kinetics of poikilotherm development. J. Theor. Biol. 64: 649-670.

Son, Y., and E. E. Lewis. 2005. Modeling temperature-dependent development and survival of Otiorhynchus sulcatus (Coleoptera: Curculionidae). Agr. Forest Entomol. 7: 201-209.

Stokstad, E. 2007. The case of the empty hives. Science 316: 970-972.

Wagner, T. L., H. I. Wu, P. J. H. Sharpe, and R. N. Coulson. 1984a. Modeling distribution of insect development rates: a literature review and application of the Weibull function. Ann. Entomol. Soc. Am. 77: 475-487.

Wagner, T. L., H. I. Wu, P. J. H. Sharpe, R. Schoolfield, and R. N. Coulson. 1984b. Modelling insect development rates: a literature review and application of a biophysical model. Ann. Entomol. Soc. Am. 77: 208-225.

Wagner, T. L., H. I. Wu, R. M. Feldman, P. J. H. Sharpe, and R. N. Coulson. 1985. Multiple cohort approach for simulating development of insect population under variable temperature. Ann. Entomol. Soc. Am. 78: 691-704.

West, T. P., and T. W. McCutcheon. 2005. Evaluating hornfaced bees (Osmia cornifrons) as pollinators of highbush blueberry. Hortscience 41: 1012-1012.

Wilson, R. L., C. A. Abel, and S. G. McClurg. 1999. Osmia spp. reared in artificial nesting sites in a backyard environment. J. Iowa Acad. Sci. 106: 4-7.

Winfree, R., N. M. Williams, J. Dushoff, and C. Kremen., 2008. Native bees provide insurance against ongoing honey bee losses. Ecol. Lett. 10: 1105-1113.

Yamada, M., N. Oyama, N. Sekiga, S. Shirasaki, and C. Tsugawa. 1971. The ecology of megachilid bee, Osmia cornifrons Radoszkowski (Hymenoptera: Apidae) and its utilization for apple pollination. Bull. Aomori Apple Exp. Station, No. 15. Aomori, Japan. 
Table1. Parameter estimate $( \pm$ SE) of the Weibull model used to estimate median time $(d)$ for diapause termination of overwintering $O$. cornifrons adults at constant temperatures

\begin{tabular}{|c|c|c|c|c|c|}
\hline \multirow{2}{*}{$\begin{array}{c}\text { Temp. } \\
\left({ }^{\circ} \mathrm{C}\right)\end{array}$} & \multirow{2}{*}{ Sex } & \multicolumn{4}{|c|}{ Weibull Model } \\
\hline & & $\alpha$ & $\beta$ & $r^{2}$ & Median (d) \\
\hline \multirow[t]{3}{*}{4} & Male & $-*$ & - & - & - \\
\hline & Female & - & - & - & - \\
\hline & Combined & - & - & - & - \\
\hline \multirow[t]{3}{*}{12} & Male & $33.54 \pm 0.69$ & $9.15 \pm 2.60$ & 0.851 & 32.2 \\
\hline & Female & $42.33 \pm 0.40$ & $11.86 \pm 1.76$ & 0.961 & 41.0 \\
\hline & Combined & $36.41 \pm 0.51$ & $5.34 \pm 0.61$ & 0.953 & 34.0 \\
\hline \multirow[t]{3}{*}{19} & Male & $13.51 \pm 0.19$ & $4.89 \pm 0.43$ & 0.979 & 12.5 \\
\hline & Female & $20.10 \pm 0.17$ & $9.45 \pm 0.94$ & 0.982 & 19.3 \\
\hline & Combined & 17.870 .13 & 4.330 .18 & 0.993 & 16.4 \\
\hline \multirow[t]{3}{*}{27} & Male & $8.30 \pm 0.16$ & $4.62 \pm 0.54$ & 0.981 & 7.7 \\
\hline & Female & $10.24 \pm 0.03$ & $8.95 \pm 0.34$ & 0.999 & 9.8 \\
\hline & Combined & $9.73 \pm 0.05$ & $5.51 \pm 0.22$ & 0.998 & 9.1 \\
\hline \multirow[t]{3}{*}{30} & Male & $5.97 \pm 0.19$ & $3.11 \pm 0.45$ & 0.971 & 5.3 \\
\hline & Female & $7.76 \pm 0.03$ & $13.41 \pm 0.93$ & 0.999 & 7.6 \\
\hline & Combined & $7.14 \pm 0.17$ & $4.12 \pm 0.54$ & 0.977 & 6.5 \\
\hline \multirow[t]{3}{*}{36} & Male & $4.12 \pm 0.20$ & $2.98 \pm 0.64$ & 0.968 & 3.6 \\
\hline & Female & & & & \\
\hline & Combined & $4.12 \pm 0.20$ & $2.98 \pm 0.64$ & 0.968 & 3.6 \\
\hline \multirow[t]{3}{*}{43} & Male & - & - & - & - \\
\hline & Female & - & - & - & - \\
\hline & Combined & - & - & - & - \\
\hline
\end{tabular}

*, no adults were emerged 
Table 2. Parameter estimate $( \pm \mathrm{SE})$ of the Weibull model to describe variability of diapause termination rate for the overwintering $O$. cornifrons adults against normalized time $(\mathrm{d} /$ median $)$

\begin{tabular}{cccc}
\hline Parameter & Male & Female & Combined \\
\hline$\alpha$ & $1.04 \pm 0.01$ & $1.04 \pm 0.01$ & $1.08 \pm 0.01$ \\
$\beta$ & $5.92 \pm 0.60$ & $9.64 \pm 0.59$ & 4.580 .21 \\
$r^{2}$ & 0.909 & 0.980 & 0.973 \\
\hline
\end{tabular}


Table 3. Parameter values $( \pm \mathrm{SE})$ and associated statistics for non-linear model (Rueda et al. 1990) for temperature-dependant diapause termination of $O$. cornifrons adults

\begin{tabular}{|c|c|c|c|c|c|c|}
\hline Sex & Parameter & Estimates (SE) & $r^{2}$ & d.f. & $\mathrm{F}$ & $\mathrm{P}$ \\
\hline \multirow[t]{4}{*}{ Male } & $\mathrm{RHO}_{25}{ }^{1}$ & $0.0926(0.00181)$ & 0.99 & 3,6 & 187.7 & $<0.001$ \\
\hline & $\mathrm{HA}^{2}$ & $16823(544.1)$ & & & & \\
\hline & $\mathrm{HH}^{3}$ & $195751(38663.8)$ & & & & \\
\hline & $\mathrm{TH}^{4}$ & 310.7 (2.09) & & & & \\
\hline \multirow[t]{4}{*}{ Female } & RHO25 & $0.0827(0.00131)$ & 0.97 & 3,6 & 109.2 & $<0.001$ \\
\hline & HA & $17862(498.5)$ & & & & \\
\hline & $\mathrm{HH}$ & $241510(54325.4)$ & & & & \\
\hline & $\mathrm{TH}$ & $305.0(1.95)$ & & & & \\
\hline \multirow[t]{4}{*}{ Combined } & RHO25 & $0.1017(0.00286)$ & 0.97 & 3,6 & 81.6 & $<0.001$ \\
\hline & HA & $13802(856.9)$ & & & & \\
\hline & $\mathrm{HH}$ & $272984(60875.7)$ & & & & \\
\hline & TH & $311.2(3.29)$ & & & & \\
\hline
\end{tabular}

${ }^{1}$ development rate at $25^{\circ} \mathrm{C}$

2 enthalpy of activation by rate controlling enzyme (cal/mol)

${ }^{3}$ change in enthalpy associated with high-temperature inactivation of enzyme (cal/mol)

${ }^{4}$ Kelvin temperature at which enzyme is one part active and one part inactive due to high temperature 


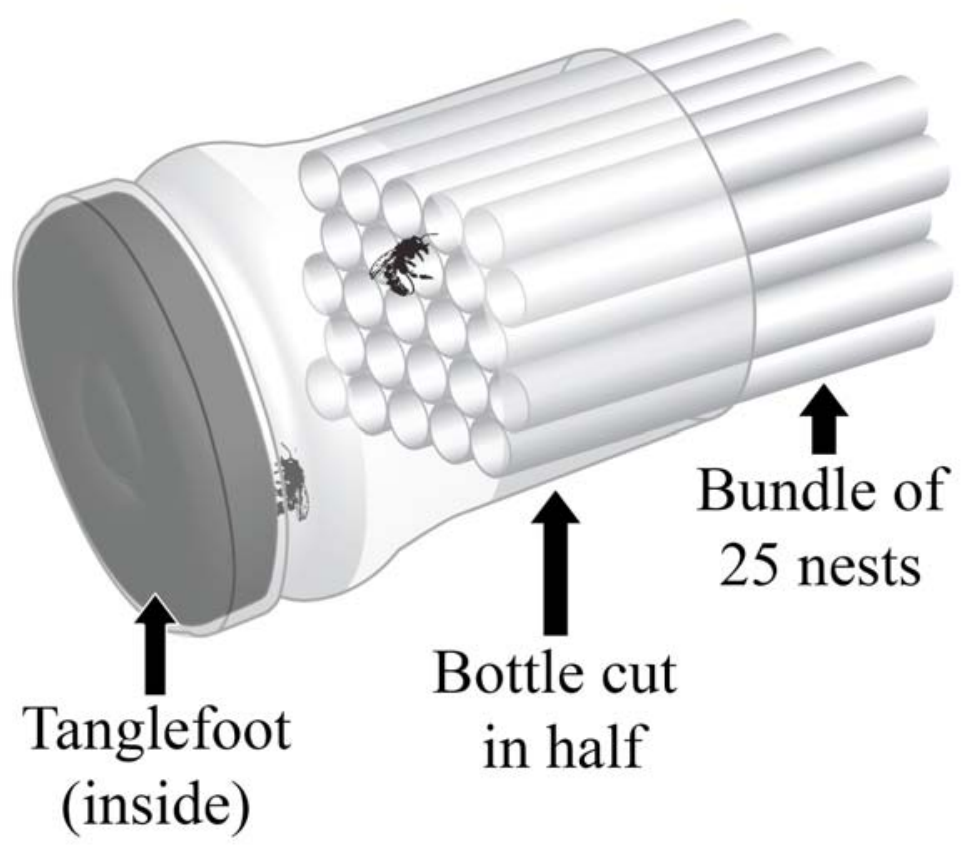

Fig. 1. Device to capture $O$. cornifrons adults after emergence to prevent them from escaping or returning back to the nests. Tanglefoot was coated inside the bottom portion of a water bottle to capture emerged $O$. cornifrons adults. 


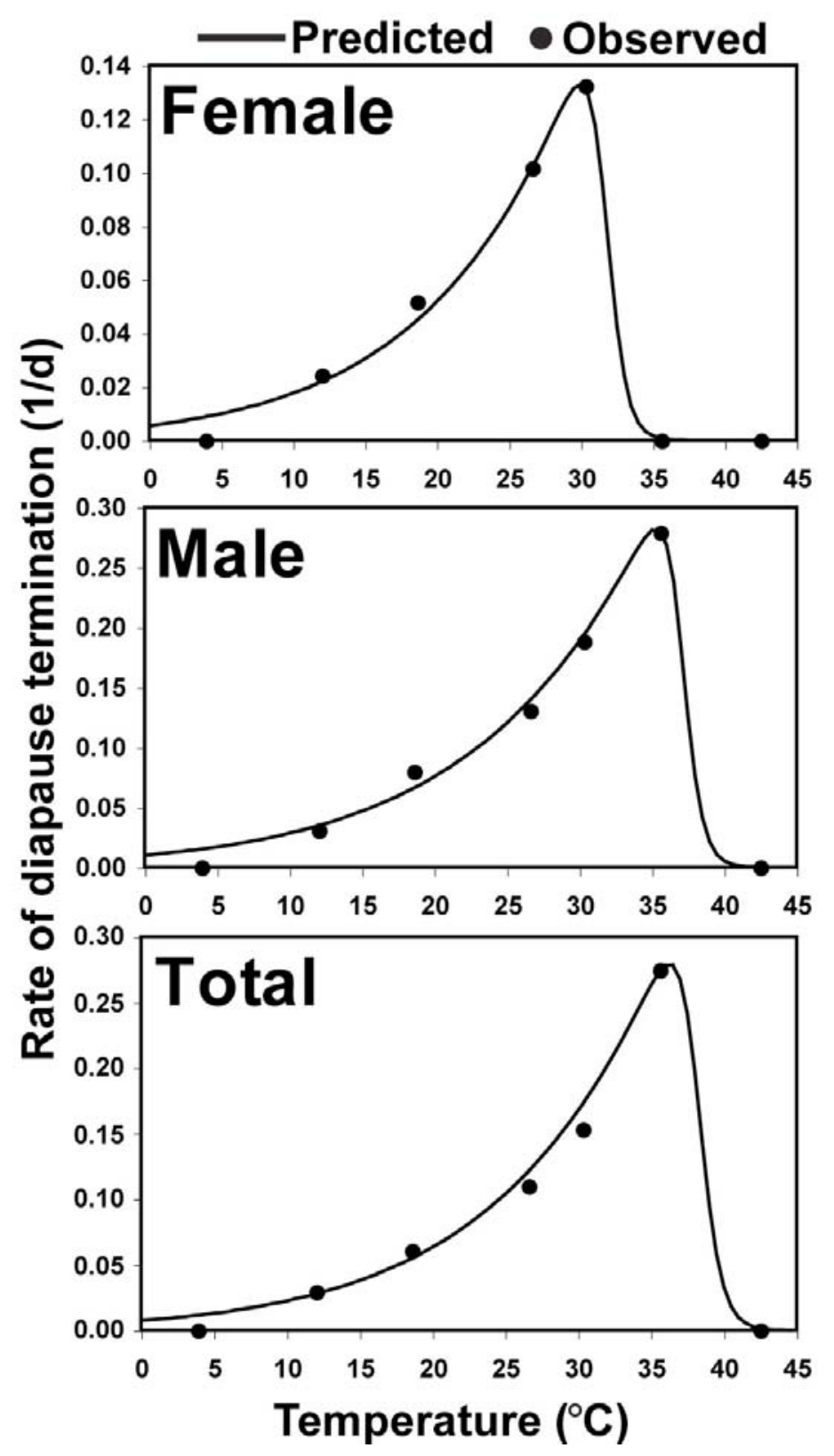

Fig. 2. Temperature-dependant diapause termination of $O$. cornifrons adults fitting with nonlinear model described by Ruena et al. (1990). See text and Table 3 for mathematical equation and parameter values for non-linear modeling. 


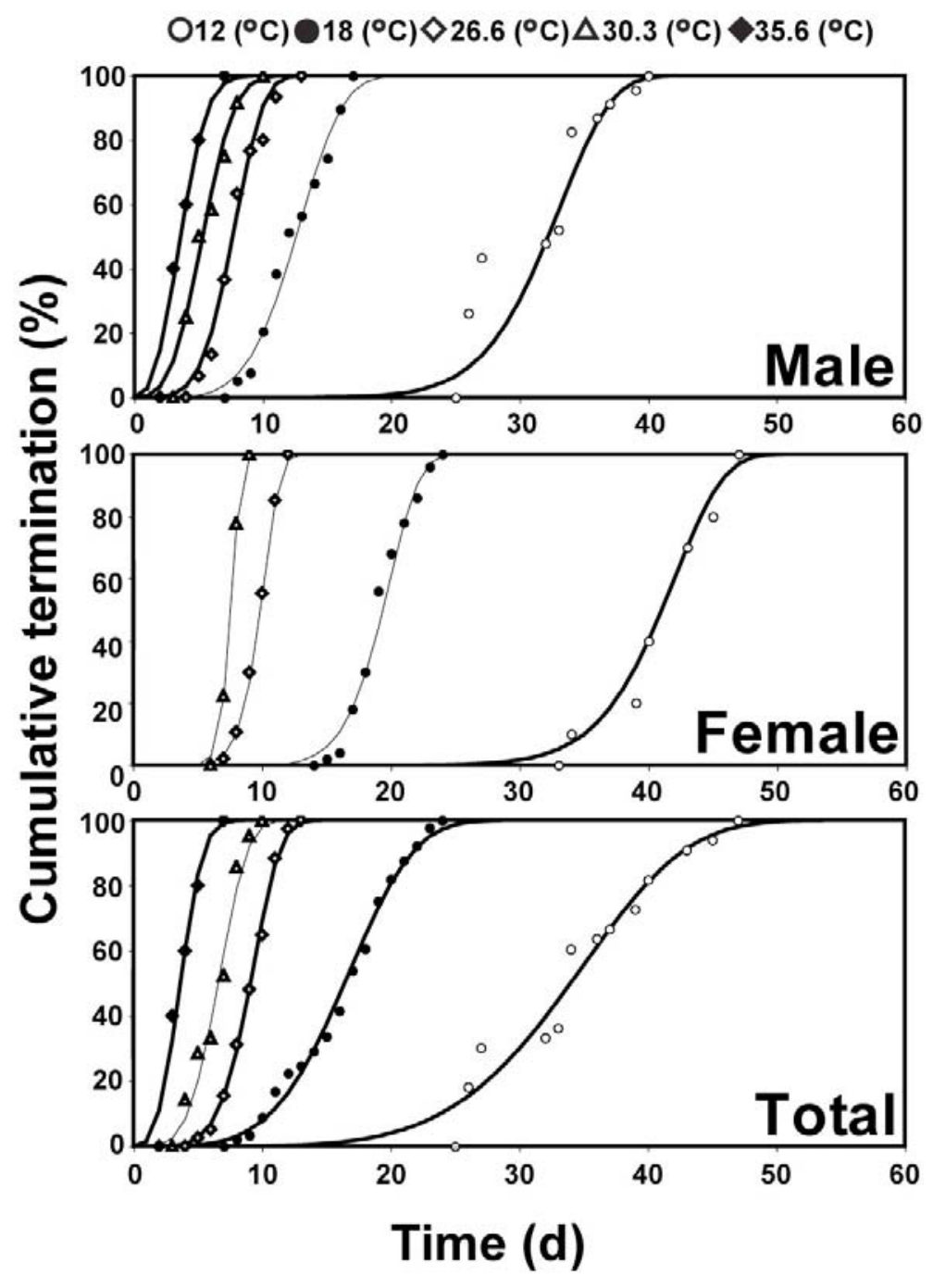

Fig. 3. Cumulative frequency (\%) of development completion for O. cornifrons adults fit with Weibull function to the cumulative frequency of normalized age (day/mean development duration). 

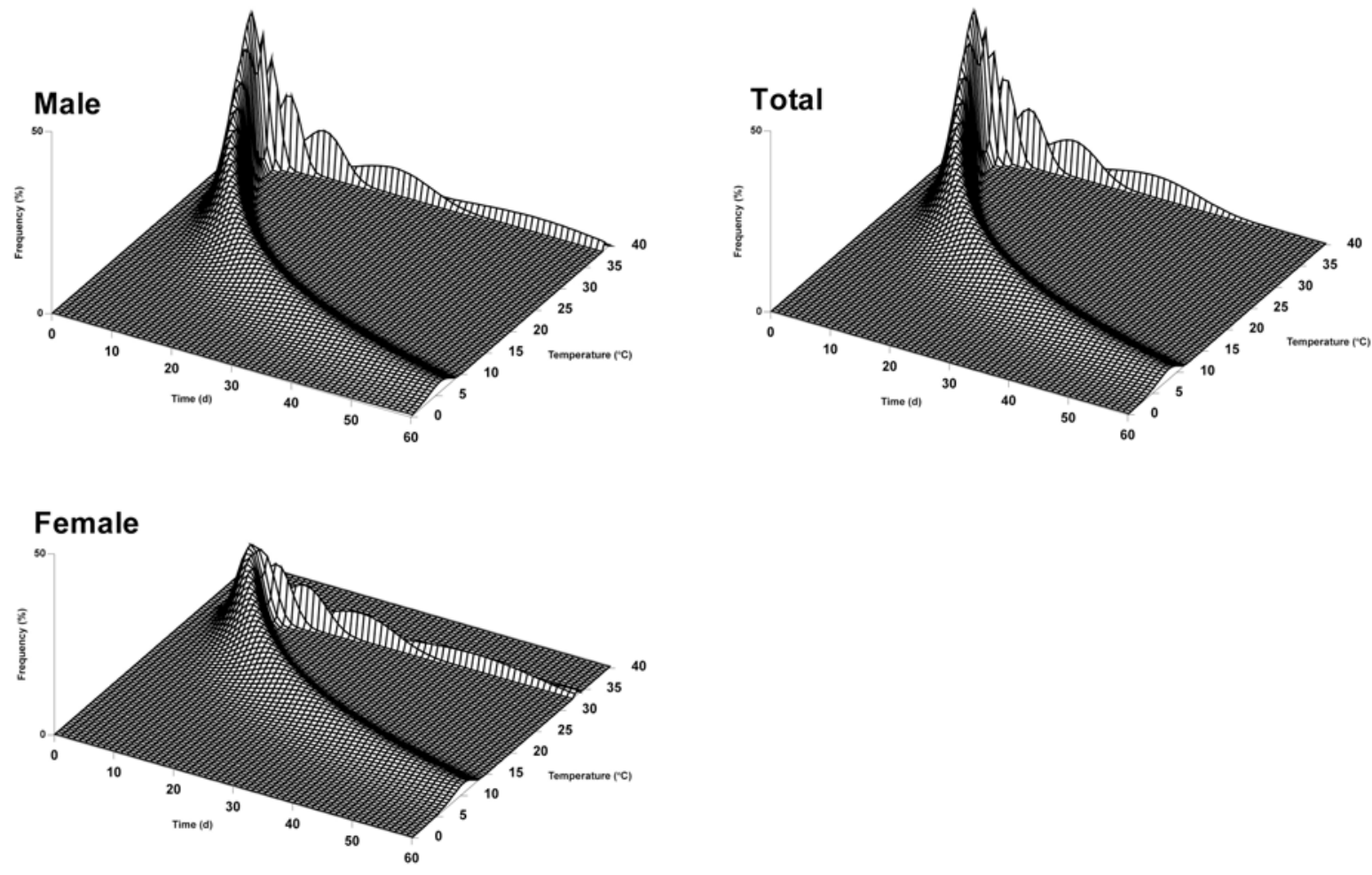

Fig. 4. Simulated temperature-dependent patterns of diapause termination of $O$. cornifrons. 


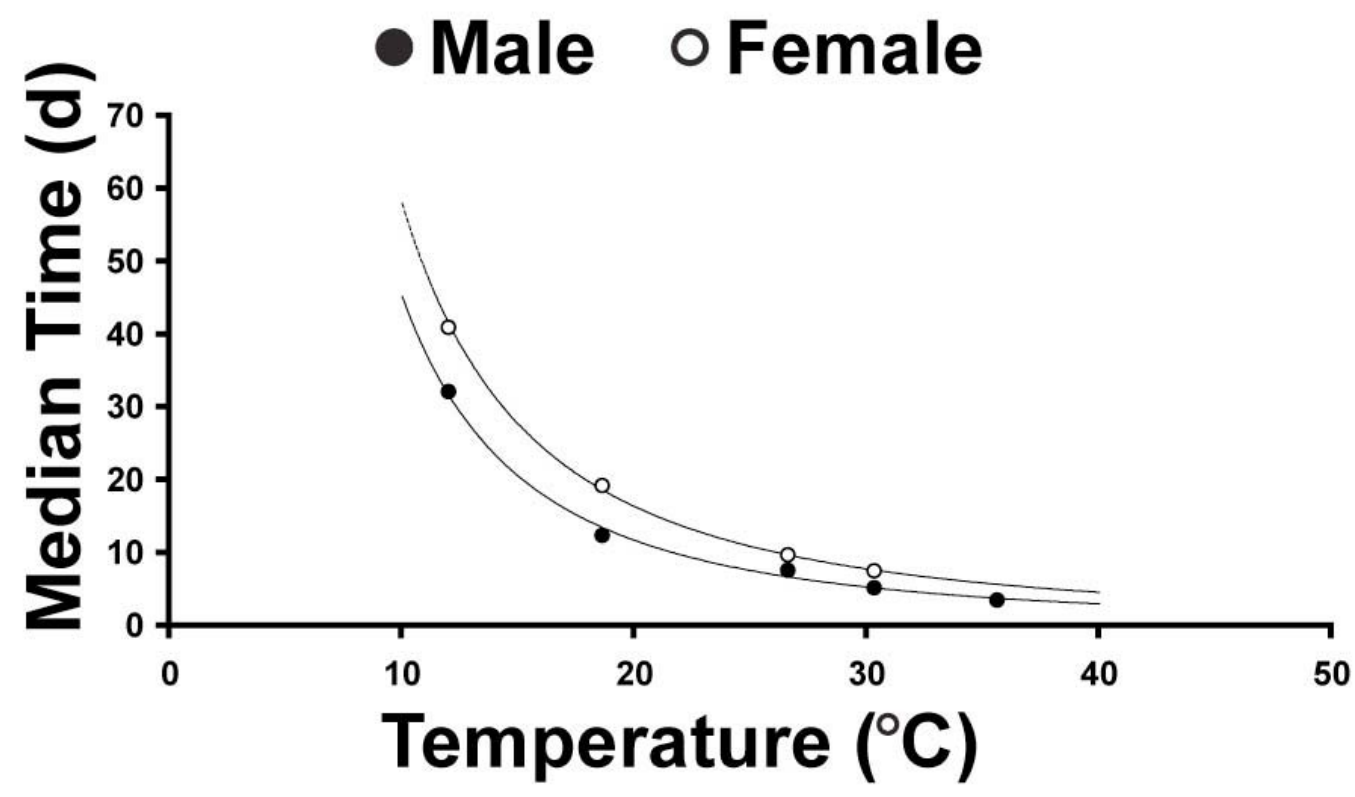

Fig. 5. Median time (d) required for diapause termination of overwintering $O$. cornifrons males and females at constant temperatures. Note that time difference in diapause termination between males and females becomes smaller as temperature increases. 


\title{
CHAPTER 3: Bioassay of Potential Fumigants to Control Chaetodactylus krombeini (Acari: Chaetodactylidae) Associated with Osmia cornifrons (Hymenoptera: Megachilidae)
}

\begin{abstract}
With the recent decline of honey bees, Apis mellifera (L.) (Hymenoptera: Apidae), alternative insects are needed for supplemental pollination. One candidate supplemental pollinator, the Japanese hornfaced bee, Osmia cornifrons (Radoszkowski) (Hymenoptera: Megachilidae) is associated with the hairy-footed mite, Chaetodactylus krombeini Baker (Acari: Chaetodactylidae) that can impede the propagation of $O$. cornifrons. This study was conducted to evaluate the efficacy of formic acid and wintergreen in controlling $C$. krombeini. This study was conducted in two bioassays: to investigate $O$. cornifrons tolerance of formic acid and wintergreen and to find the lethal concentration of formic acid and wintergreen needed for mite control. We found that $O$. cornifrons could tolerate low doses of both formic acid and wintergreen for extended periods of time. The time and dosage required to induce $C$. krombeini mortality with either formic acid or wintergreen was significantly less than the time required to produce $O$. cornifrons mortality. Estimates of the $\mathrm{LC}_{50}$ and $\mathrm{LC}_{90}$ for $C$. krombeini hypopi treated with wintergreen were ca. five times lower than those with formic acid, indicating that wintergreen was a more effective mite control tactic. Mortality of $O$. cornifrons was low when exposed to either formic acid or wintergreen for up to 20 minutes. This study provides evidence that $C$. krombeini can be managed effectively without inducing mortality in $O$. cornifrons.
\end{abstract}

Keywords: formic acid, essential oil, wintergreen, hornfaced bee, hairy-footed mite 
Crop and fruit tree pollination is a 15 billion dollar industry each year in the United States (Morse and Calderone 2000). With recent events such as parasitic mites (Finley 1995), Africanized honeybees (Sammataro and Avitable 1998) and Colony Collapse Disorder (Stokstad 2007) contributing to the decline of honeybees there is a need to consider alternate means of pollination, such as with the Japanese hornfaced bee, Osmia cornifrons (Radoszkowski) (Hymenoptera: Megachilidae) (Adams 2001). Osmia cornifrons has been used successfully for the pollination of apple in Japan (Sekita and Yamada 1993), and since its introduction to the United States in 1976 (Batra 1998), it has been used for the pollination of spring blooming fruit trees (Batra 1998, Adams 2001) and vegetable crops (Wilson et al. 1999). Because the life cycle of the bee coincides well with blueberry flowering it is particularly useful in blueberry pollination (West and McCutcheon 2005). Osmia cornifrons is also timid and rarely stings, which makes using the bee in commercial orchards attractive to growers (Batra 1998, Bosch and Kemp 2001).

Under natural conditions, Osmia spp. (e.g., O. cornifrons and $O$. lignaria) can be found nesting in reeds. In commercial settings it is, however, commonly managed in small cardboard tubes used as nests (Batra 1998, Bosch and Kemp 2001). Osmia cornifrons is gregarious and the tubes facilitate their use in a targeted area. Osmia cornifrons constructs cells with mud partitions within the tubes and these tubes can be grouped together in bundles. While this makes management easier it also provides an attractive habitat for pests such as parasitic wasps and mites, by increasing bee density it in turn provides an increase in density of pests (Krunić et al.2005, Park et al. 2009).

One pest associated with $O$. cornifrons is the hairy-footed mite, Chaetodactylus krombeini Baker (Acari: Chaetodactylidae), and it is of particular importance with respect to $O$. 
cornifrons propagation and management (Park et al. 2009). Chaetodactylus krombeini is a pollen mite that infests the tubes in which Osmia spp. nest (Bosch and Kemp 2001). Chaetodactylus krombeini hypopi enters nesting tubes in a variety of ways. Park et al. (2009) found that $C$. krombeini hypopi were capable of walking from adjacent tube openings as well as through holes in tubes created by parasitic wasps, and a major dispersal mechanism is through phoretic behavior. When $C$. krombeini hypopi hitchhike on $O$. cornifrons adults, hypopi become entangled in the hairs of the bee. We observed that $O$. cornifrons adults are visibly irritated when infested by $C$. krombeini and some adults had difficulty flying because of the number of mites on the bee. Once hypopi enter the tubes their population can increase to 170 to 5000 mites per cell (Park et al. 2009). Chaetodactylus krombeini populations will compete with $O$. cornifrons larvae for pollen provision in the tubes and have been reported to kill developing larvae (Bosch and Kemp 2001). Larvae that do survive may experience a reduction in size due to a decreased food supply during development (Bosch and Kemp 2001). A reduction in larval size may also cause a corresponding reduction in pollinating efficiency as adults.

Currently $C$. krombeini is controlled by cultural methods such as physically removing $O$. cornifrons cocoons (Krunic' et al. 2005) and cleaning them with bleach (Bosch and Kemp 2001), or with heat treatments (Sekita and Yamada 1993). However, these methods have several disadvantages. Physically removing cocoons disturbs the bees' natural nesting behavior. Cleaning with bleach requires the removal from the nesting tube and presents further complications when the cocoons are exposed to bleach treatment. Thus, additional, less invasive control methods that allow $O$. cornifrons to remain undisturbed would benefit their use as a supplemental pollinator (Park et al. 2009). 
Mites associated with honeybees have been effectively controlled by both formic acid and essential oils (Amrine 2006). A non-intrusive method, such as fumigation, would be best suited for pest control of $O$. cornifrons because disturbances to the bees may cause a reduction in the number of females returning to nesting tubes to lay eggs (Bosch and Kemp 2001). This study was conducted to evaluate formic acid and wintergreen to determine if the volatile nature of these compounds would effectively control $C$. krombeini hypopi without impacting $O$. cornifrons.

\section{Materials and Methods}

Experimental animals. Osmia cornifrons and C. krombeini hypopi were obtained from a local grower in Independence, West Virginia who has been using the $O$. cornifrons to pollinate blueberry for the last $10 \mathrm{yr}$. The grower has used cardboard tubes $(7.9 \mathrm{~mm}$ diameter, $0.8 \mathrm{~mm}$ thickness, and $152 \mathrm{~mm}$ length, Jonesville Paper Tube Co., Jonesville, MI) as artificial nests for O. cornifrons.

Bioassay of formic acid and wintergreen on O. cornifrons. Mortality of $O$. cornifrons adults was determined by exposure to various volumes of $50 \%$ formic acid and wintergreen oil. Both $50 \%$ formic acid and wintergreen oil have been shown to kill mites associated with honeybees while not producing harmful side effects to the honeybees (Amrine 2006). Bioassays were conducted under ambient environment $\left(23 \pm 2.1^{\circ} \mathrm{C}\right.$ and $\left.58 \pm 6.2 \% \mathrm{RH}\right)$. For the bioassay arena, we used 56.6- $\mathrm{cm}^{3}$ Petri dishes (3-cm radius with 2-cm depth, Lab-Tek ${ }^{\circledR}$ 4036, LAB-TEK Division Miles Laboratories, Inc., Naperville IL) with 55-mm-diameter filter paper (Whatman ${ }^{\circledR}$ 1001-055, Whatman International Ltd, Maidstone England) taped onto the lid of the Petri dish. Seven different volumes $\left(0,5,10,20,40,60\right.$ and $80 \mu 1$ per $\left.56.6 \mathrm{~cm}^{3}\right)$ of $50 \%$ formic acid 
(Chemical and Solvents Inc., Roanoke, VA) or artificial wintergreen oil, Methyl Salicylate Synthetic (Lorann Oils, Lansing, MI) were applied to the filter paper using micropipettes. One $O$. cornifrons adult female who had emerged from a cleaned cocoon was placed inside the Petri dish and then the Petri dish was wrapped with Parafilm ${ }^{\circledR}$ (American National Can ${ }^{\mathrm{TM}}$, Neenah, WI). Time required to cause death of each $O$. cornifrons adult was recorded and the bioassay was replicated five times for each amount and chemical. Data were analyzed with ANOVA and comparisons among treatments were based upon Tukey's HSD test at $0.05 \%$ error rate (PROC GLM, SAS Institute 2008).

Bioassay of formic acid and wintergreen on C. krombeini. Mortality of C. krombeini hypopi exposed to various amounts of $50 \%$ formic acid and wintergreen was conducted using the same design as previously mentioned. A total of $28 \pm 11.7$ C. krombeini hypopi were placed in a Petri dish with a fine brush. Four different amounts $\left(0,5,10\right.$, and $20 \mu 1$ per $\left.56.6 \mathrm{~cm}^{3}\right)$ of $50 \%$ formic acid or wintergreen were applied to the filter paper using micropipettes. The Petri dish and lid were sealed with parafilm and mortality was recorded at intervals of 0, 5, 10 and 15 min. We set these time intervals and amounts based on our preliminary study that showed that both formic acid and wintergreen were effective at $<20 \mu \mathrm{l}$ when applied under $20 \mathrm{~min}$. However, because the size of $C$. krombeini hypopi is ca. $\approx 0.3 \mathrm{~mm}$ (Park et al. 2009) and they are generally very active when they are out of the nest, accurately counting the number of dead and live mites can be very difficult and time consuming and prone to observation error. Therefore, we developed an image analysis approach as a more practical and effective method of recorded mite mortality.

Images were taken with a digital camera (Sony ${ }^{\circledR}$ Model DCS-W50, Sony Corporation of America, New York, NY) at intervals of 0, 5, 10 and 15 min. These images were processed and 
analyzed with Photoshop CS3 Extended ${ }^{\circledR}$ (Adobe Systems Inc., San Jose, CA) to count the number of dead and live hypopi (Figure 1). Images taken from each Petri dish at each time interval were overlaid and any movements of hypopi were detected with the 'difference' blend mode function in Photopshop $\mathrm{CS}^{\circledR}$. This function made it possible to align two images and look at the differences in pixels between the two images. When movement of hypopi was detected between two images, the function detected the difference in pixels, and the hypopi were considered alive; otherwise, they were considered dead. These steps were repeated with successive images in the time series. When live hypopi were detected, the mites were digitally marked and automatically counted with the 'analysis' function in Photoshop CS3 Extended ${ }^{\circledR}$. Mortality of hypopi for each chemical amount and time interval was calculated.

Total numbers of dead individuals for each treatment were corrected against the control using Abbott's formula (Abbott 1925). Corrected data were subjected to logit analysis to determine the main effects of dose and treatment, and their interaction (PROC GENMOD, SAS Institute 2008). Overdispersion in data was corrected using the scaled deviance parameter in SAS. Significance of effects was based upon the likelihood ratio chi-squared. Logit analysis was used to estimate $\mathrm{LC}_{50}$ and $\mathrm{LC}_{90}$ (Robertson et al. 1984, Stokes et al. 2000). In addition, the two chemical treatments were compared for treatment effects using survival analysis (PROC LIFE TEST, SAS Institute 1999) to determine interactions among treatment, dose and time.

\section{Results}

Bioassay of formic acid and wintergreen with $\boldsymbol{O}$. cornifrons adults. When formic acid was directly applied to $O$. cornifrons, the dense hairs of the body seemed to considerably prevent the chemical from coming into contact with the body of the bee. Consequently there was no 
mortality. In contrast, wintergreen quickly soaked into the dense hairs on $O$. cornifrons resulting in death (Fig. 2). Bees that came into direct contact with wintergreen became highly irritated and were observed to shake and twitch. When formic acid and wintergreen were applied as volatiles, $O$. cornifrons adults could survive for $111.5 \mathrm{hr}$ with low-dosage applications of wintergreen (Table 1). Osmia. cornifrons lived much longer in the presence of wintergreen than in formic acid at doses of $<20 \mu 1$ per $56.6 \mathrm{~cm}^{3}$. However, at higher doses $\left(>60 \mu 1\right.$ per $\left.56.6 \mathrm{~cm}^{3}\right)$, O. cornifrons lives slightly longer when in the presence of formic acid than wintergreen.

Bioassay of formic acid and wintergreen with . krombeini hypopi. The logit analysis showed significant effects of dose $\left(\chi^{2}=14.31\right.$; df. $\left.=1 ; P<0.001\right)$, treatment $\left(\chi^{2}=19.46\right.$; df $=1$; $P<0.001)$, and their interaction $\left(\chi^{2}=17.28 ; \mathrm{df}=1 ; P<0.001\right)$. Highly significant differences between formic acid and wintergreen was also confirmed by survival analysis $\left(\chi^{2}=1355.7\right.$; $\mathrm{df}=$ $1 ; P<0.0001)$. When homogeneity among doses and time was tested for wintergreen only, the survival of $C$. krombeini hypopi at 10,15 , and $20 \mu 1$ per $56.6 \mathrm{~cm}^{3}$ was statistically the same across all time intervals $\left(\chi^{2}=2.6, \mathrm{df}=2, P=0.2758\right)$; however, when these amounts were grouped together, they as a group were significantly different from the control $\left(\chi^{2}=465.4\right.$, df $=$ 1, $P<0.0001$ ) (Fig. 3). When testing formic acid alone, the concentration of $10 \mu 1$ was not significantly different from the control $\left(\chi^{2}=3.4\right.$; $\left.\mathrm{df}=1 ; P=0.0644\right)$. However, this group was significantly different that the $15 \mu$ concentration $\left(\chi^{2}=63.9 ; \mathrm{df}=1 ; P<0.0012\right)$, which was in turn significantly different than the $20 \mu$ concentration $\left(\chi^{2}=10.5\right.$; $\left.\mathrm{df}=1 ; P<0.0012\right)$ (Fig. 3). Estimates of the $\mathrm{LC}_{50}$ and $\mathrm{LC}_{90}$ for $C$. krombeini hypopi treated with wintergreen were ca. five times higher than those with formic acid (Table 2). Survival analysis also showed that $C$. krombeini survival subjected to wintergreen decreased rapidly at $5 \mathrm{~min}$. while survival was sustained twice as long when subjected to formic acid (Fig. 3). 


\section{Discussion}

Formic acid and wintergreen have been used to control parasitic mites associated with honeybees such as the varroa mite, Varroa destructor (Mesostigmata: Varroidae) and the tracheal mite, Acarapis woodi (Prostigmata: Tarsonemidae). Amrine et al. (2006) showed that formic acid and essential oils killed the mites but did not affect the honeybee. They also showed that formic acid could be applied as a fumigant and has been used as a low cost method that achieves $90-95 \%$ mortality of the mites. This study showed that $O$. cornifrons adults generally tolerated the fumigant properties of formic acid and wintergreen $(<5 \mathrm{~min}$. with applications of $<$ $20 \mu 1$ per $56.6 \mathrm{~cm}^{3}$ ) that successfully killed hypopi, indicating the potential for $C$. krombeini control. In addition, we also observed that $O$. cornifrons adults reacted differently when physical contact of $50 \%$ formic acid and wintergreen was made on the body of the adult bee.

Chaetodactylus krombeini is currently managed in several different ways, both mechanically and chemically. Heat treatments have been used for C. krombeini control (Bosch and Kemp 2001), and when nests of Osmia spp. infested with C. krombeini were exposed to high temperatures, the bees remained alive while the mites died. Another approach to control $C$. krombeini is the use of binder boards (i.e., boards with the appropriate sized hole drilled through and then cut in half) allowing the user to pry the two pieces of the board apart, gaining access to the cocoon inside (Strickler 2002). The binder boards can be used for C. krombeini control by opening the boards and removing the cocoons to separate those infested with C. krombeini. Cocoons that have been removed from binder boards also can be washed with a bleach solution (Strickler 2009). Binder boards and nesting materials can also be treated directly with endosulfan (Krunic' et al. 2005). However, all of these methods may produce adverse side 
effects. Cocoons and nesting materials could come into direct contact with any chemicals used, which can cause chemical residue to remain inside the nesting materials. Also, the physical removal of $O$. cornifrons from the binder boards generally results in releasing loose cocoons and may increase unwanted dispersal of pre-nesting female bees (Bosch and Kemp 2001); generally females will leave their nesting tubes to feed for a few days and then return to oviposit, while those females who have been released outside of their nesting tube have a greater chance of not returning to oviposit. This study showed that formic acid and wintergreen were very effective in killing C. krombeini hypopi in a short time period and could be used to reduce the side effects associated with current $C$. krombeini management tactics. Formic acid and wintergreen can be used as a volatile and thus they would allow the bees to remain undisturbed in the nest or binder board during application. This can reduce pre-nesting dispersal by females and potentially increase O. cornifrons populations in the subsequent year (Bosch and Kemp 2001). It would also allow the bees to avoid direct contact with the substance, which would reduce the likelihood of residual effects.

This study suggests two considerations on the utilization of formic acid and wintergreen to control C. krombeini. First, formic acid and wintergreen need to be used as fumigants because O. cornifrons adults can be killed by the direct contact with them. In parasitic mite control in honeybee hives, formic acid volatiles are circulated throughout the bee hive by wing fanning, penetrating the brood cells, and thereby killing the parasitic mites (Amrine et al 2006). Wintergreen for mite control in honeybee hives is generally used as an ingredient to grease patties, on which the honeybees feed on and slowly emit volatiles to kill mites. Honeybees will feed on grease patties and as they do the wintergreen acts as an irritant to the varroa mite causing the mite to fall off the bee and through the frames of the hive to the bottom board (Amrine 2006). 
However, this method may not be directly applicable to the case with $O$. cornifrons because $O$. cornifrons adults do not ventilate air inside the nest that is partitioned with mud. Also, old nests that are intended for use in the future need to be fumigated with formic acid or wintergreen to control C. krombeini when bees do not inhabit the nests. When binder boards are used, the boards could be spread open allowing the fumigant to contact the mites. Due to the short application period required, active bees may be treated outside of their nests as they emerge. However, further studies are needed to investigate practical and effective methods of applying both formic acid and wintergreen as a volatile for control of C. krombeini.

\section{Acknowledgments}

We thank Bob McConnell for providing Osmia cornifrons for this experiment. We also thank Jim Amrine, and Vicki Kondo at West Virginia University for their valuable suggestions related to this experiment. This project was supported by the Division of Plant and Soil Science at West Virginia University and the Sustainable Agriculture Research and Education Grant program.

\section{References Cited}

Abbott, W.S. 1925. A method of computing the effectiveness of an insecticide. J, Econ. Entomol. 18: 265-267.

Adams, L. R. 2001. Determination of accumulation of degree days required for the emergence of Osmia cornifrons (Megachillidae) in Pennsylvania. M.S. thesis. Pennsylvania State University, College Park, PA.

Amrine, J. W. 2006. Wintergreen + Salt Grease Patties http://www.wvu.edu/ agexten/varroa/GresPates.pdf 
Amrine, J. W. and R. Noel. 2006. Formic acid fumigator for controlling varroa mites in honey bee hives. Int. J. Acarol. 32: 115-124.

Batra, S. W. T. 1998. Management of hornfaced bees for orchard pollination. University of Idaho, Moscow, ID.

Bosch, J., and W. P. Kemp. 2002. Developing and establishing bee species as crop pollinators: the example of Osmia spp. (Hymenoptera : Megachilidae) and fruit trees. Bull. Entomol. Res. 92: 3-16.

Finley, J. V. 1995. Acaricide treatments of tracheal and varroa mite infestations of honeybees, and the development of geopgraphically-referenced menthol treatment recommendations of Pennsylvania. M.S. thesis

Krunić, M., L. Stanisaljevic, M. Pinzauti, and, A. Felicioli. 2005. The accompanying fauna of Osmia cornuta and Osimia rufa and effective measures of protection. Bullet. Insect. 58: $141-152$.

Morse, R.A., and N.W. Calderone. 2000. The value of honey bees as pollinators of U.S. crops in 2000. Bee Cult. 128: 2-15.

Park, Y. L., V. Kondo. J. White, T. West, B. McConnell, and T. McCutcheon. 2009. Nest-tonest dispersal of Chaetodactylus krombeini (Acari, Chaetodactylidae) associated with Osmia cornifrons (Hym., Megachilidae). J. Appl. Entomol. 133: 174-180.

Robertson, J. L., K. C. Smith, N. E. Savin, and R. J. Lavigne. 1984. Effects of dose selection and sample size on the precision of lethal dose estimates in dose-mortality regression. J. Econ. Entomol 77:833-837.

Sammataro, D. B., and A. Avitable. 1998. The Beekeeper's Handbook $3^{\text {rd }}$ Edition. Cornell Press, NY. 190 pages. 
SAS Institute. 2008. SAS OnlineDoc ${ }^{\circledR}$ version 9.1.3. SAS Institute. Cary, NC.

Sekita, N., and M. Yamada. 1993. Use of Osmia cornifrons (Radoszkowski) for pollination of apples in Aomori Prefecture, Japan. Jap. Agric. Res. Quart. 26: 264-270.

Strickler, K. 2009. Winter Cocoon Management.

http://www.pollinatorparadise.com/Solitary_Bees/Winter_Cocoon_Management.htm\#Rem oving_loose_cocoons.

Strickler, K., and J. Mills 2002. Loose cell management systems for solitary bees.

http://www.pollinatorparadise.com/Binderboards/Osmiabb.htm

Stokes, M. E., C. S. Davis, and G. C. Koch. 2000. Categorical data analysis using the SAS system, $2^{\text {nd }}$ ed. SAS Institute, Cary NC.

Stokstad, E. 2007. The case of the empty hives. Science 316: 970-972.

Wilson, R. L., C. A., Abel, and R.I. Luhman. 1999. Comparing three bee species for controlled pollination of selected Brassicaceae. J. Iowa Acad. Sci. 106: 1-3. 
Table 1. Required hours to death of $O$. cornifrons adults with formic acid and wintergreen treatments

\begin{tabular}{ccc}
\hline $\begin{array}{c}\text { Dosage Amount } \\
\left(\mu 1 \text { per } 56.6 \mathrm{~cm}^{3}\right)\end{array}$ & Formic acid & Wintergreen \\
\hline 0 & $21.9 \pm 2.6 \mathrm{a}^{*}$ & $132.5 \pm 42.7 \mathrm{a}$ \\
5 & $10.1 \pm 2.1 \mathrm{a}$ & $11.5 \pm 81.1 \mathrm{~b}$ \\
10 & $8.3 \pm 2.9 \mathrm{~b}$ & $18.5 \pm 4.8 \mathrm{~b}$ \\
20 & $8.0 \pm 3.3 \mathrm{~b}$ & $9.9 \pm 5.3 \mathrm{~b}$ \\
40 & $6.2 \pm 2.4 \mathrm{~b}$ & $5.5 \pm 2.5 \mathrm{~b}$ \\
60 & $5.2 \pm 2.8 \mathrm{~b}$ & $3.5 \pm 0.7 \mathrm{c}$ \\
80 & $3.7 \pm 0.7 \mathrm{~b}$ & $3.1 \pm 0.7 \mathrm{c}$ \\
100 & $5.7 \pm 2.6 \mathrm{~b}$ & $2.6 \pm 0.5 \mathrm{~b}$ \\
120 & $6.2 \pm 2.2 \mathrm{~b}$ & $2.7 \pm 1.0 \mathrm{~b}$ \\
140 & $4.8 \pm 0.5 \mathrm{~b}$ & $1.8 \pm 0.9 \mathrm{c}$ \\
\hline
\end{tabular}

"Means within each variable in each column followed by the same letter are not significantly different $(\mathrm{P}>0.05$; Tukey's standardized range test). 
Table 2. Estimates of lethal concentration $\left(\mathrm{LC}_{50}\right)$ of wintergreen $(\mathrm{WG})$ and formic acid $(\mathrm{FA})$ in O. cornifrons

\begin{tabular}{lcccccc}
\hline & $\mathrm{LC}_{50}$ & $\mathrm{LC}_{50}-\mathrm{UCL}^{1}$ & $\mathrm{LC}_{50}-\mathrm{LCL}^{2}$ & $\mathrm{LC}_{90}$ & $\mathrm{LC}_{90}-\mathrm{UCL}^{1}$ & $\mathrm{LC}_{90}-\mathrm{LCL}^{2}$ \\
\hline WG & 3.1 & 10.9 & 0.9 & 5.7 & 20.2 & 1.6 \\
FA & 15.4 & 15.8 & 14.9 & 23.4 & 24.2 & 22.7 \\
\hline
\end{tabular}

${ }^{1}$ UCL, Upper confidence limit

${ }^{2}$ LCL, Lower confidence limit 


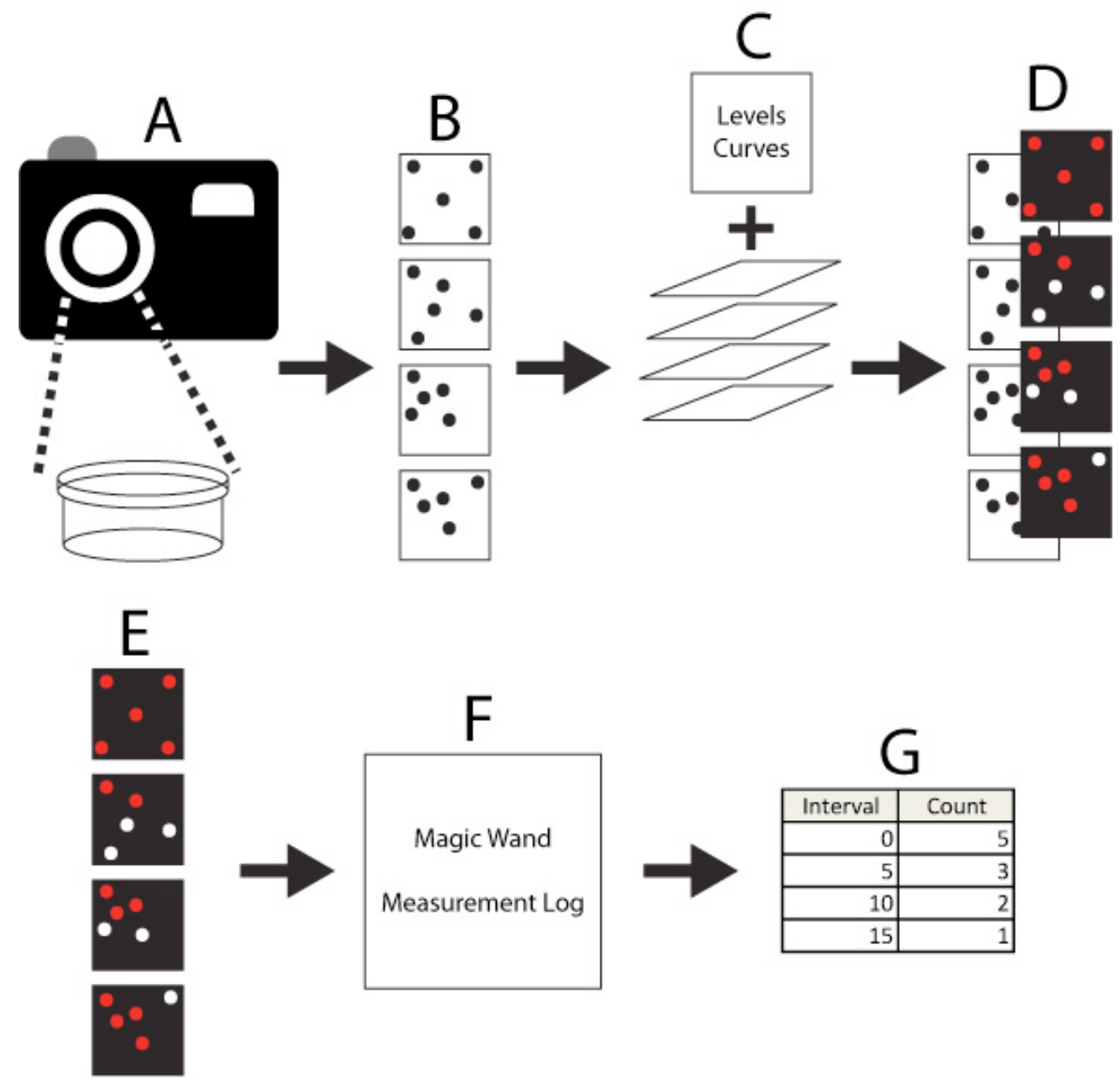

Figure 1: Procedures of image analysis to count numbers of $C$. krombeini hypopi using Adobe Photoshop CS3 Extended. (A) Digital camera used to take 4 images of mites in Petri dish, one image per interval at 0, 5, 10 and 15 minutes. (B) 4 images combined and layered in 1 Photoshop document. (C) Levels and curves adjustment layers used to add additional contrast to images. (D) 4 blank layers added over original images and mites were marked on each new layer with paintbrush tool. Blank layers were set to Difference blend mode to allow changes in movement to appear in each subsequent image. (E) Final processed images show mite movement at each interval. (F) Magic Wand tool used to select the mites that have been marked on each layer. Measurement Log used to count the number of selected mites and export the data. (G) Exported data was opened in Microsoft Excel and analyzed. 


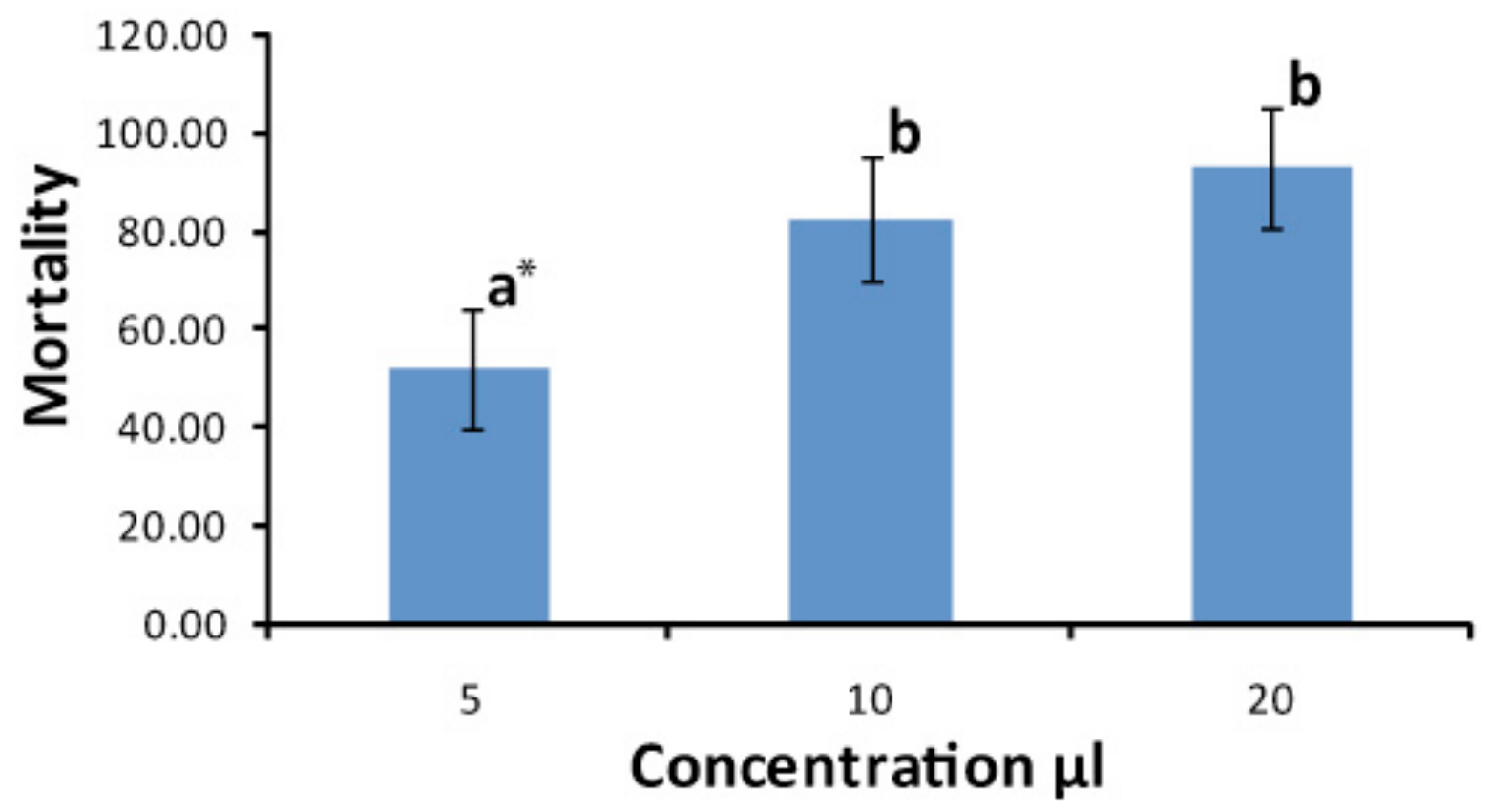

Figure 2: Mortality of $O$. cornifrons adults when wintergreen was applied directly to the bee. *, means within each variable in each column followed by the same letter are not significantly different $(\mathrm{P}>0.05$; Tukey's standardized range test). 


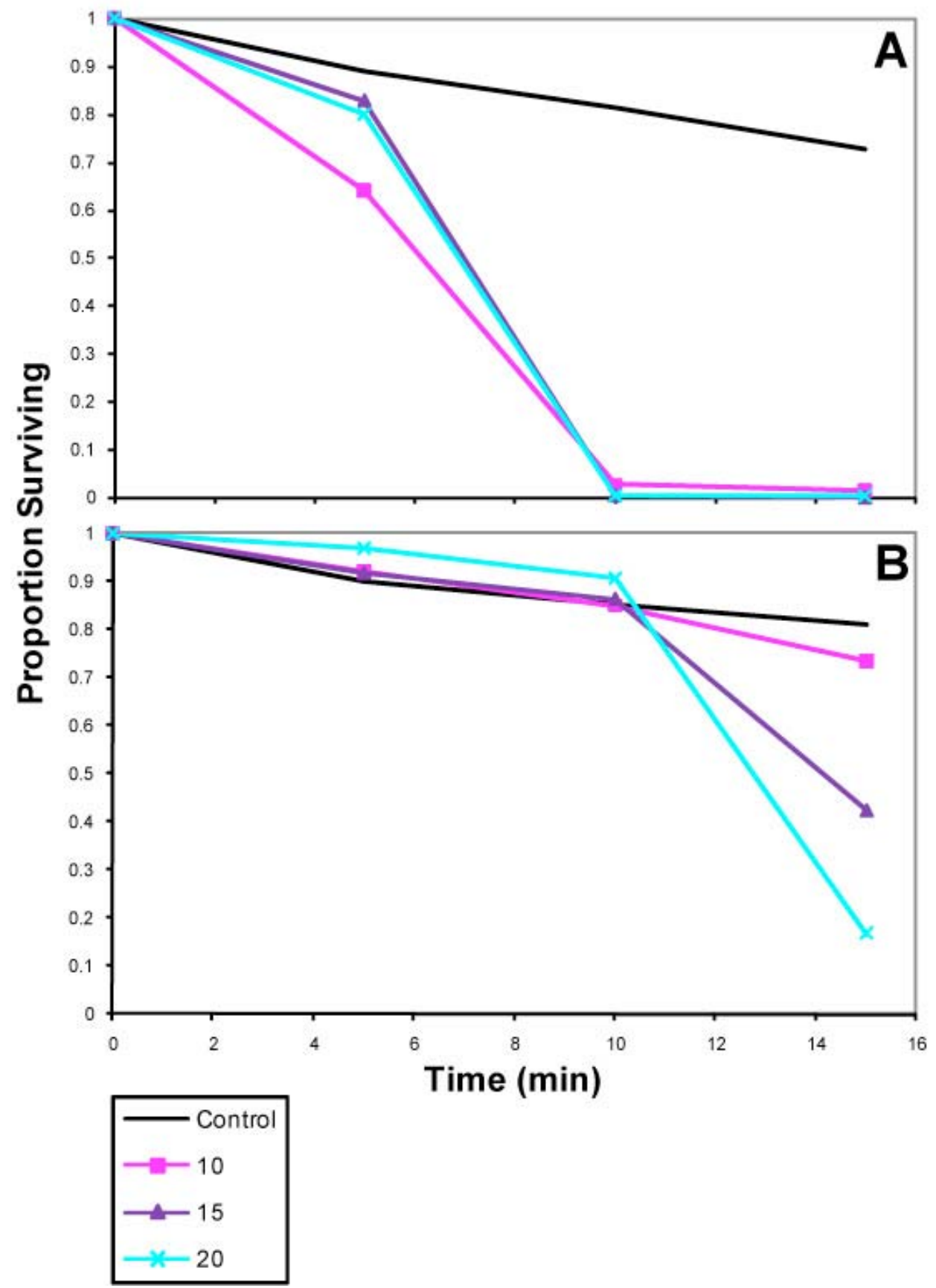

Figure 3: Survivor analysis of C. krombeini hypopi when fumigated with (A) wintergreen and (B) formic acid at three different amount of application: 0 (control), 5, 10, and $20 \mu 1$ per 56.6 $\mathrm{cm}^{3}$. 


\section{CHAPTER 4: CONCLUSION}

Osmia cornifrons adults spend a very short period of their life cycle engaged in pollination. Therefore, it is crucial to synchronize the termination of $O$. cornifrons adult diapause with the blooming period of the target plant to maximize pollination. Currently, $C$. krombeini, a pest associated with $O$. cornifrons, has been of particular importance with respect to O. cornifrons propagation and management.

The result of this study (Chapter 1) indicates two major applications of diapause termination of $O$. cornifrons adults for pollination. First, the lower and higher temperature thresholds can be used to determine temperatures for proper storage and termination of diapausing $O$. cornifrons adults during the winter. Diapausing $O$. cornifrons adults would need to be stored under the lower temperature threshold during the winter to maintain diapause, and under the high temperature threshold to avoid mortality. Second, knowing the degree day requirements for $O$. cornifrons adult emergence allows for a more goal oriented release of $O$. cornifrons adults. With the use of a model of diapause termination patterns, a greater synchronization of adult bee emergence with the pollination periods of target fruit trees can be achieved. However, trade-offs exist between expedited termination of diapause and decreased bee abundance. Depending on various factors in each orchard such as the size of managing $O$. cornifrons colonies, climatic conditions, and fruit tree varieties varying blooming periods diapause manipulation can be goal-oriented to achieve the desired response.

This study (Chapter 2) also considers the implications of management strategies for $C$. krombeini. Formic acid and wintergreen need to be used as fumigants because $O$. cornifrons adults can be killed by the direct contact with them. Old nests that are intended for use in the future need to be fumigated with formic acid or wintergreen to control C. krombeini when bees 
do not inhabit the nests. When binder boards are in use, the boards could be spread open

allowing the fumigant to contact the mites. Due to the short application period required, active bees may be treated outside of their nests as they emerge. However, further studies are needed to investigate practical and effective methods of applying both formic acid and wintergreen as a volatile for control of C. krombeini.

\section{References Cited}

Amrine, J. W. 2006. Wintergreen + Salt Grease Patties

http://www.wvu.edu/ agexten/varroa/GresPates.pdf

Bosch, J., and W. P. Kemp. 2002. Developing and establishing bee species as crop pollinators: the example of Osmia spp. (Hymenoptera : Megachilidae) and fruit trees. Bull. Entomol. Res. 92: 3-16. 